University of Pennsylvania Carey Law School

Penn Law: Legal Scholarship Repository

Faculty Scholarship at Penn Law

6-30-2004

\title{
Our Corporate Federalism and the Shape of Corporate Law
}

\author{
Marcel Kahan \\ New York University Law School \\ Edward B. Rock \\ University of Pennsylvania Carey Law School
}

Follow this and additional works at: https://scholarship.law.upenn.edu/faculty_scholarship

Part of the Business Organizations Law Commons

\section{Repository Citation}

Kahan, Marcel and Rock, Edward B., "Our Corporate Federalism and the Shape of Corporate Law" (2004). Faculty Scholarship at Penn Law. 46.

https://scholarship.law.upenn.edu/faculty_scholarship/46

This Article is brought to you for free and open access by Penn Law: Legal Scholarship Repository. It has been accepted for inclusion in Faculty Scholarship at Penn Law by an authorized administrator of Penn Law: Legal Scholarship Repository. For more information, please contact PennlawIR@law.upenn.edu. 


\title{
Our Corporate Federalism and the Shape of Corporate Law
}

\author{
Marcel Kahan* \& Edward Rock ${ }^{* *}$
}

Draft 6/30/04

Do not cite or quote without permission

* Crystal Eastman Professor of Law, New York University School of Law. Marcel Kahan’s research was supported by the Filomen D’Agostino and Max E. Greenberg Research Fund.

** Saul A. Fox Distinguished Professor of Business Law, University of Pennsylvania School of Law Edward Rock's research was supported by the Institute for Law and Economics, the Saul A. Fox Research Endowment, and the Milton and Miriam Handler Foundation.

We thank Bill Allen, Larry Kramer, Linda Silberman [others] and participants in the U.S.C./UCLA 2003 Corporate Law Roundtable for helpful comments. 


\begin{abstract}
In the public debate sparked by the corporate scandals of the last years, Delaware has been strikingly absent. In contrast to the high profile activity of Congress, the Securities and Exchange Commission, the stock exchanges, federal prosecutors, and even state law enforcement officials, Delaware has been largely mute: no legislation; no rule-making; no criminal investigations; few headlines. In this Article, we use Delaware's relative passivity during this latest episode of corporate law-making as a starting point in the analysis of the shape of American corporate federalism and Delaware's place within it.
\end{abstract}

We argue that Delaware long ago opted for what we will call a "classical" or " $19^{\text {th }}$ century" common law model of corporate law-making. In Delaware, corporate law is largely judge-made; judicial opinions are filled with quasi-deterministic reasoning; statutory law is comparatively narrow and rarely subject of partisan disputes; the judiciary as well is relatively non-partisan and has claim to technical expertise; and the law is enforced through litigation brought by private parties. We view these traits through the lens of the institutional and political landscape in which Delaware must operate. This landscape is characterized by a federalist system in which Delaware's regulatory powers co-exist with, and can be constrained by, the powers of the federal government. In this system, Delaware is faced with the threat that populist pressures will lead to a federal preemption of Delaware corporate law and thus eradicate the huge profits Delaware derives from being the domicile of choice for public-traded U.S. corporations. By creating and enhancing an apolitical gloss over Delaware's corporate law, the various traits we identify help shield Delaware against this threat. At the same time, the scope of Delaware's corporate law is designed to minimize conflicts by assuring that Delaware has the requisite personal jurisdiction over defendants to enforce its law effectively and that the prevailing conflict rules point to substantive Delaware law as applicable to a corporate law dispute.

But this classical model of law making carries with it intrinsic limitations. Specifically, legal change is slow, standard-based and incremental. Faced with the recent corporate scandals, calls for action, and Sturm und Drang, Delaware reacted accordingly: Basically, it does nothing until cases are brought. Any more pro-active response by Delaware actors would have threatened to undermine the political legitimacy achieved by Delaware's commitment to the classical common law model. But because the classical common law style, together with jurisdictional and conflict rules, constrain Delaware, federal law is needed to complement Delaware's. In that respect, the relation between federal law and Delaware law is symbiotic, rather than antagonistic: Delaware is happy to have federal law pick up the slack and thereby reduce the likelihood that ineffective regulation produces a populist backlash. 


\section{Table of Contents}

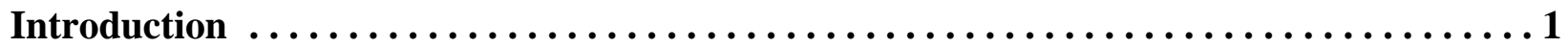

I. The Landscape of Corporate Law Making $\ldots \ldots \ldots \ldots \ldots \ldots \ldots \ldots \ldots$

A. The Institutions of Corporate Law Making $\ldots \ldots \ldots \ldots \ldots \ldots \ldots$

B. The Politics of Federal Intervention $\ldots \ldots \ldots \ldots \ldots \ldots \ldots \ldots \ldots \ldots \ldots$

II. Salient Traits of Delaware Corporate Law $\ldots \ldots \ldots \ldots \ldots \ldots \ldots \ldots \ldots$

A. The Breadth of Judge-Made Law $\ldots \ldots \ldots \ldots \ldots \ldots \ldots \ldots \ldots \ldots$

B. The Quasi- Deterministic Style of Delaware’s Judge-Made Law . . . . . . 17

C. The Making of Delaware's Statutory Law $\ldots \ldots \ldots \ldots \ldots \ldots \ldots \ldots$

D. Distinctive Features of Delaware's Judiciary $\ldots \ldots \ldots \ldots \ldots \ldots \ldots$

E. The Reliance on Private Enforcement $\ldots \ldots \ldots \ldots \ldots \ldots \ldots \ldots \ldots \ldots$

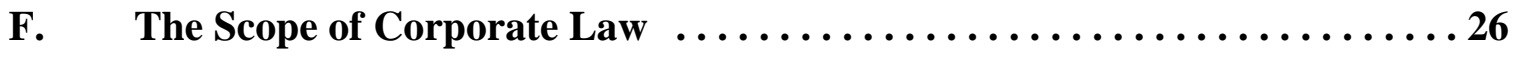

III. Delaware's Traits as Adaptations to the Political Landscape . . . . . . . . . . . 27

A. Embracing Common Law Classicism: The Creative Use of Anachronism? 28

B. Preserving the Technocratic and Apolitical Gloss $\ldots \ldots \ldots \ldots \ldots \ldots \ldots$

C. The Minimization of Interjurisdictional Conflict $\ldots \ldots \ldots \ldots \ldots \ldots \ldots$

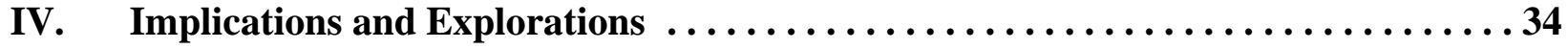

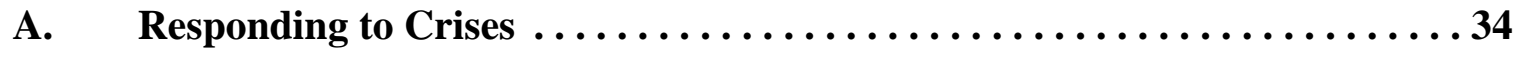

B. The Symbiotic Relationship between Federal Law and Delaware Law . . . 35

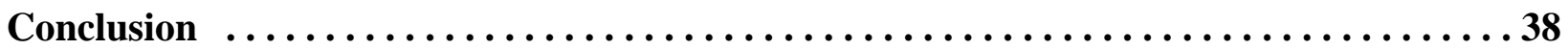




\section{Introduction}

Enron. Worldcom. Adelphia. Global Crossing. Tyco. Corporate scandals have made the front pages. Congress has gotten in the act. Members have held numerous hearings, given speeches, and, ultimately, passed the Sarbanes-Oxley Act. The Securities and Exchange Commission has been busy writing regulations and leaning on the stock exchanges to modify their listing requirements, all in order to restore "investor confidence." Federal prosecutors have indicted executives of Enron, Worldcom, and Adelphia and their minions in the auditing and investment banking industry. State officials have also been active. Several states have passed statutes that resemble or go beyond the strictures of Sarbanes-Oxley. ${ }^{1}$ Robert Morgenthau, the Manhattan District Attorney, has indicted the CEO and others officers of Tyco. ${ }^{2}$ And Eliot Spitzer, New York's Attorney General, has taken on the brokerage houses and, perhaps following in the footsteps of Rudolf Giuliani, another renowned prosecutor of corporate criminals, vastly increased his political standing. The leaders of corporate America have been galvanized to action, forming committees and task forces, issuing reports, and giving speeches.

But where has Delaware been through all this? No bills have been introduced in Delaware's legislature; no hearings held by its committees; its law enforcement agents have taken no action; and its executives have staid mum. How is it that Delaware - the home of what has long been viewed as the de facto national corporate law - has sat on the sidelines?

In this Article, we take a step back from the recent scandals and the responses it has generated and ask some logically prior questions. What is the structure of corporate law making in the United States? What is the relation between federal and state corporate law making? ${ }^{3}$ And how does that relationship shape the style and content of Delaware's corporate law? In a sense, we are asking an old question: what is the corporate "legal process"? ${ }^{4}$

\footnotetext{
${ }^{1}$ Zealous States Shake Up Legal Status Quo -- Oklahoma's MCI Case Is Latest Headache for Federal Officials and Corporate Lawyers, WALL ST. J., Aug. 28, 2003, at A4 (noting that 20 have passed or are considering their own version of the Sarbanes-Oxley Act, and that some of the laws are tougher than the federal regulations); Governor Signs Bill to Tighten Corporate Accounting Practices, SEC. \& L. RPTR., Sep. 2, 2002, at 1446 (describing California measures going beyond those of Sarbanes-Oxley Act).

${ }^{2}$ See District Attorney - New York County News Release, Sep. 12. 2002, available at www.manhattanda.org/whatsnew/press/2002-09-12.html (announcing indictment of Tyco's former CEO, CFO and Chief Corporate Counsel).

3 The literature on this question is expanding. Important recent contributions include Stephen Bainbridge, The Creeping Federalization of Corporate Law, REGULATION (Spring 2003); Mark Roe, Delaware’s Competition, 117 HARV. L. REV. 588 (2003); Robert Thompson, Corporate Governance After Enron, 40 HoUSTON L. REV. 99 (2003); Robert Thompson \& Hillary Sale, Securities Fraud as Corporate Governance: Reflections on Federalism, 56 VANDERBILT L. REV. 859 (2003).

${ }^{4}$ And, in answering that question, we turn back to the classic articulation, Henry M. Hart, Jr. \& Albert M. Sacks, The Legal Process: Basic Problems in the MaKing AND ApPliCATion Of LAW (William Eskridge \& Philip Frickey, eds. 1994).
} 
From this legal process perspective, we argue that Delaware long ago opted for what we will call a classical or $19^{\text {th }}$ century common law model of law making. We argue further that this serves to preserve Delaware's status as a significant maker of corporate law. But this old model of law making entails some intrinsic limitations, including that legal change is slow, standardbased and incremental. These limitations explain how Delaware responded to the recent corporate scandals and, in turn, create a space where the relationship between federal law and Delaware law is symbiotic rather than antagonistic.

In Part I, we analyze the institutional and political landscape of corporate law-making. Although Delaware exercises a significant law-making role, it is faced with an omnipresent specter of a federal takeover, which could eradicate the substantial income the state derives from franchise fees. The principal threat for Delaware is the possibility that federal intervention will be triggered by a situation in which systemic change generates significant populist political payoffs. This danger is aggravated by Delaware's apparent lack of democratic legitimacy: why should a small state set national policy for corporate law? It is in Delaware's interest to structure its law to minimize its exposure to such an attack. In addition, Delaware must take account of the rules on personal jurisdiction and on conflicts of law embedded in the federal structure.

Part II identifies a number of salient traits that characterize Delaware's corporate law. Most important and controversial legal rules are the product of judge-made law. Judicial opinions are filled with quasi-deterministic reasoning. Statutory amendments to the corporation law are initially drafted by a bar committee, are adopted without change and debate by the legislature, and address largely technical and non-controversial matters. Delaware's judiciary has substantial expertise on corporate law and is non-political. In contrast to Delaware's firstrate system for the private enforcement of corporate law rules, public enforcement is virtually non-existing. And the scope of corporate law is largely confined to the regulation of the internal affairs of a corporation.

In Part III, we argue that these traits can be understood as adaptations to the political and institutional landscape in which Delaware operates. In many respects, Delaware's corporate law may the last vestige of the classical 19th century common law model in America: most important legal rules are promulgated by a nonpartisan, expert judiciary; these rules are presented as derived from long-standing and widely accepted principles; the law is enforced through civil litigation brought by private parties; and even legislative amendments generate neither debate or controversy. All this has the effect of creating and enhancing a technocratic, apolitical gloss over Delaware's corporate law and thus helps to shield Delaware from being attacked for the lack of democratic legitimacy. At the same time, the scope of Delaware's corporate law is designed to minimize conflicts by assuring that Delaware has the requisite personal jurisdiction over defendants to enforce its law effectively and that the prevailing conflict rules point to substantive Delaware law as applicable to a dispute.

In Part IV, we assess Delaware's response to the recent corporate scandals and the division of corporate law-making roles between Delaware and the federal government. We argue that Delaware's response to the scandals - or rather the lack thereof - flows from its 
adherence to the classical common law model. Faced with corporate scandals, calls for action, and Sturm und Drang, Congress held hearings and passed sweeping legislation and Eliot Spitzer crusaded against Wall Street. But Delaware has to wait until a legal dispute is brought in its courts, and even then can address the issues only in an incremental fashion. While this means that Delaware has been out of the limelight, and may have hurt Delaware's image in the short term, staying out of the political limelight is in Delaware's long-term interest. Spitzer may be a successful politician, and he may even be the right Attorney General for New York, but he would not be the best person to assure that hundreds of millions in annual franchise fees keep flowing into Delaware's coffers. But because the classical common law style, together with jurisdictional and conflict rules, constrain Delaware, federal law is needed to complement Delaware's. This is so where Delaware's common law regime cannot effectively supply the optimal legal regime - e.g. because it is requires public enforcement or is highly regulatory - or where the rules on personal jurisdiction or conflicts inhibit Delaware's ability to regulate. In that respect, the relation between federal law and Delaware law is symbiotic, rather than antagonistic: Delaware is happy to have federal law pick up the slack and thereby reduce the likelihood that ineffective regulation produces a populist backlash.

\section{The Landscape of Corporate Law Making}

In this Part, we examine the division of corporate law making between federal and state authorities. We provide a stylized description of two related landscapes of corporate law-making - the institutional and the political - and analyze the powers of and constraints placed on lawmaking by federal actors and by Delaware.

\section{A. The Institutions of Corporate Law Making.}

Figure 1 provides a simplified overview of the allocation of corporate law-making authority in the United States. Congress sits at the top of the chart. There is little constitutional doubt that, if Congress wished to legislate a national corporate law that would displace all state corporate law, it could do so pursuant to its power under the Constitution's Commerce Clause. ${ }^{5}$

Given this authority, Congress faces several options. It can legislate corporate law directly, enacting either a comprehensive corporate law or discrete elements. It can set relatively broad standards and then establish an administrative agency, such as the Securities and Exchange Commission, with subsidiary lawmaking powers. It can set broad standards and leave it to courts to adjudicate cases and develop the law through a common law process. It can enact enabling provisions which leave the task of making specific rules to the domain of private choice. Or it can do nothing and thereby leave the regulation of corporate conduct to the states.

\footnotetext{
${ }^{5}$ See Roe, supra note 3, at 607-620 (discussing topics where federal rules have displaced state rules). For a fuller discussion of the constitutionality of such Congressional action, see footnote _ infra..
} 
If Congress is willing to allow the states to act, the states then face similar options: to legislate directly; to establish an administrative agency; to let courts develop rules through the common law process; or to enact enabling provisions. In addition, states must determine the applicable “choice of law” rules: should the applicable law be the law of the corporation's state of incorporation, should it be the law of its principal place of business, or should a forum state apply its own law even if the ties of the corporation to the state are more tenuous? ${ }^{6}$

Abstracting for the moment from public choice concerns (to be covered in the next section), a public-regarding legislature, in deciding how best to legislate in the corporate area, would need to consider a variety of factors. First, there is the question of institutional competence. Promulgating detailed fine-grained rules requires a certain level of institutional infrastructure that an administrative agency, like the Securities and Exchange Commission may possess, but that a legislature is likely to lack. Second, there is the question of the appropriate degree of decentralization: Is a uniform national rule optimal? Is it better to allow for diversity among the states? To what extent should companies be permitted to set their own rules?

But Figure 1 only provides part of the picture. For people who focus on corporate law, a picture of corporate lawmaking that puts Congress at the top and the Delaware courts, as a subset of other state courts, towards the bottom fails to capture who the important corporate law actors are.

If one focuses not on lawmaking power but on lawmaking role, a different picture emerges. Consider, in this regard, Figure 2. Figure 2 recognizes that courts, in the process of resolving disputes, often have the first opportunity to address problems through law-making. As Hart \& Sacks pointed out:

In the development of Anglo-American legal systems, courts have functioned characteristically as the place of initial resort for the settlement of problems which have failed of private solution. ... [T] he body of decisional law announced by the courts in the disposition of these problems tends always to be the initial and continues to be the underlying body of law governing the society. Legislatures and administrative agencies tend always to make law by way not of original solution of social problems, but by alteration of the solutions first laid down by the courts. ${ }^{7}$

The Hart \& Sacks notion of courts as first-line law-makers provides an important modification of the picture of law-making authority in Figure 1. In the first instance, a myriad of corporate law disputes are brought to the Delaware Chancery Court. Other corporate law disputes are brought

${ }^{6}$ State legislatures' freedom of action in this regard may be subject to some Constitutional constraints. See Edgar v. MITE Corp., 457 U.S. 624, 645 (1982) (Illinois antitakeover statute that applied to companies with tenuous contact to state violates Commerce clause).

${ }^{7}$ Hart \& Sacks, supra note 4, at 163 - 164. 
to the federal courts or the courts of other states. ${ }^{8}$ In resolving these disputes, courts will often be the first body to address a problem though law-making.

Consider Figure 2 in more detail. Controversies arise among corporations, managers, investors and between corporations and employees, regulators, citizens and others. When these controversies become legal disputes, they can go either to the Delaware courts, other state courts, or the federal system. Which forum parties resort to for litigating their disputes, in turn, is influenced and sometimes determined by two additional elements peculiar to the U.S. federal system. The first element concerns personal jurisdiction. Under the due process clause of the U.S. constitution, state courts can assert jurisdiction only over defendants who have the requisite minimum contacts with the forum state. The second concerns the rules on conflict of laws. These rules, which are part of the law of each state, determine the law of which jurisdiction applies to a dispute. Under the prevailing rules on conflict of laws, the law of the state of incorporation governs the internal affairs of the corporation. However, with respect to other issues, these rules will rarely point to the law of the state of incorporation as governing a dispute.

But, as shown in Figure 2, public controversies will occasionally avoid the legal machinery entirely. Instead, such controversies are brought to the Securities and Exchange Commission or directly to either the state legislature or to the U.S. Congress. Moreover, once a legal dispute has been adjudicated by the courts, parties interested in the legal rule ${ }^{9}$ promulgated face a decision whether to accept the result or to seek to have it changed. For disputes adjudicated within the Delaware system, the choices are to turn to the Delaware legislature, ${ }^{10}$ to go to the Securities and Exchange Commission ${ }^{11}$, or to turn to Congress. ${ }^{12}$ Similarly, parties dissatisfied with the legal rules emerging from federal court adjudications can turn either directly to Congress or to the SEC. ${ }^{13}$

${ }^{8}$ See, e.g., Moore Corp. v. Wallace Computer Services, 907 F.Supp. 1545 (D. Del. 1995).

${ }^{9}$ By parties, we mean interest groups and political actors that have a stake in the legal rule announced in a case, rather than the specific parties to the litigation.

${ }^{10}$ An example of this is the enactment of Section 102(b)(7) in the wake of Smith v. Van Gorkom, 488 A.2d 858 (Del. 1985).

${ }^{11}$ An example here is the SEC's reversal of the discriminatory self-tender defense sanctioned in Unocal. See Dennis J. Block et al., ThE BusinESS JudGMENT RulE (5th ed. 1998) at 1010.

${ }^{12}$ An example is the prohibition of loans to executives in the Sarbanes-Oxley Act. See Roberta Romano, The Sarbanes-Oxley Act And the Making of QuACK Corporate Governance, Working Paper 2004.

${ }^{13}$ See infra Section I.A. (detailing several instances where rules on insider trading announced by federal courts have been reversed by Congress or the SEC). Since federal courts sometimes also interpret state law, some federal court rulings can also be reversed by state legislatures. 
While, in Figure 1, members of the Delaware judiciary may appear to be little more than secondary actors, Figure 2 indicates that Delaware judges can have a critical role. ${ }^{14}$ Whether they do or not depends on where disputes are litigated and how often the Delaware legislature or federal lawmakers intervene. As discussed in Part II, Delaware courts adjudicate, in the first instance, most corporate law disputes involving public corporations that raise issue addressed by state law ${ }^{15}$ and the Delaware legislature rarely intervenes. As discussed in Part III, this manner of law-making serves to fend-off federal intervention.

\section{B. The Politics of Federal Intervention}

Figures 1 and 2 also provide a starting point for understanding the politics of federal intervention in corporate law making. Generally, Delaware exercises the first-line rule-making role for much of corporate law, mostly because Delaware courts are in the forefront of resolving corporate disputes. A significant prospect of change can arise only if a significant interest group is highly dissatisfied or if political actors foresee political benefit from advocating legal change. ${ }^{16}$ Even when there is a prospect for such change, however, there are forces pushing back.

${ }^{14}$ Ronald Dworkin, LAW’s EMPIRE, at 239-74; Ronald Dworkin, TAKING RIGHTS SERIOUSLY, at Chapter 4.

${ }^{15}$ For a contrary view, see Thompson \& Sale, supra note 3.

${ }^{16}$ Our view of the threat of federal intervention thus differs in subtle, but important, ways from Mark Roe's recent insightful analysis of the issue. Roe regards the federal authorities as having some independent substantive policy preferences. In order not to trigger federal intervention, state rules must match or come close to these preferences. See Roe, supra note 3, at 607. As discussed in this section, we see federal intervention as a product of either interest group lobbying (where interest groups have both preferences for the actual content of legal rules and the identity of the regulator) or populist politics and regard the latter as the more serious threat. 
Consider the possibility of Congressional intervention: ${ }^{17}$ suppose that some politicians become convinced that interstate competition for corporate charters results in a race to the bottom $^{18}$ or favor a federal takeover of state corporate law for more naked political considerations. How might parties favoring the status quo resist such a move?

One possible argument might be constitutional, namely, that such a wholesale displacement of state corporate law would be beyond Congress's powers under the Commerce Clause. As a matter of contemporary Constitutional law, this is a weak - indeed, nearly laughable - argument. ${ }^{19}$ In light of Congress's constitutional ability to intercede directly and to

\footnotetext{
${ }^{17}$ Piecemeal reform can also come from the Securities and Exchange Commission, with a somewhat different sort of political dynamic. See, e.g., Mark Maremont \& Deborah Solomon, Behind SEC's Failings: Caution, Tight Budget, '90s Exuberance, WALL ST. J., Dec. 24, 2003, at A1 (describing various reasons for SEC's cautious approach to regulation); Headline Risk at the SEC, Wall St. J., May 10, 2004, at A16 (accusing SEC of adopting cumbersome regulations for their headline value). Historically, there have been a variety of more or less pervasive SEC incursions into the traditional topics of Delaware corporate law. The more confined incursions include rules governing: going private transactions; tender offers; and dual class re-capitalizations. The more pervasive ones include the proxy rules that govern shareholder voting and insider trading rules. Without delving deeply into the politics of agency rule-making, one can note that the Securities and Exchange Commission is subject to many of the same pressures as Congress, and that, when the key constituencies are satisfied with the status quo, SEC attempts to expand its reach can usually be resisted. And of course, the SEC can only act to the extent that Congress has delegated the requisite authority and can be overridden by Congresses or the courts if it steps out of line. See Business Roundtable v. SEC, 905 F.2d 406 (D.C. Cir. 1990).

Stock exchanges also have the ability to act, either on their own behest or because of SEC pressure. While the exchanges have wider latitude to make corporate law rules than the SEC does, they are constrained by their desire to attract listings and by competition from other exchanges. They may thus be reluctant to adopt rules opposed by managers who exercise control over where companies are listed (more so than over where they are incorporated). More fundamentally, exchanges lack enforcement powers. The most serious sanction - delisting - is hardly credible when there are competing exchanges, and, moreover, hardly a consolation for shareholders who are supposedly helped by the rules. For this reason, only clear-cut rules by the exchanges that create no ex post ambiguities have real bite (if a violation is obvious, most companies won't dare to do it, even if enforcement is weak). See generally Edward B. Rock, Securities Regulation as Lobster Trap: A Credible Commitment Theory of Mandatory Disclosure, 23 CARDOZO L. REV. 675 (2002).

${ }^{18}$ See, e.g., Lucian Arye Bebchuk, Federalism and the Corporation: The Desirable Limits on State Competition in Corporate Law, 105 HARV. L. REV. 1435 (1992) (arguing that state competition leads to rules biased towards managerial interests); William L. Cary, Federalism and Corporate Law: Reflections upon Delaware, 88 YALE L.J. 663 (1974) (arguing that state competition results in a race to the bottom).
}

19 There is no plausible constitutional argument that Congress would not have the power, under the Commerce Clause, to preempt state corporate law with a national corporate law. Article I, section 8, of the U.S. constitution (the "Commerce Clause") grants Congress the power to "regulate Commerce with foreign Nations and among the Several States." This has been expansively interpreted. For good, comprehensive discussions, see Laurence H. Tribe, AMERICAN CONSTITUTIONAL LAW (3d Ed. 2000) §§5-4 - 5-5; Erwin Chemerinsky, Consitutional Law: Principles And Policies (2d Ed. 2002) § 3-3. From 1937 to 1995, the Supreme Court did not hold a single Congressional action to be beyond the regulatory power conferred by the Commerce Clause. Id. During this period, for example, the Supreme Court held that Congress had Commerce Clause power to regulate stock in public utilities, American Power \& Light Co. v. SEC, 329 U.S. 90 (1946) and to regulate interstate insurance transactions, US v. South-Eastern Underwriters Association, 322 U.S. 533 (1944). Indeed, the Commerce Clause is the sole jurisdictional basis for all of federal securities regulation. 
shift corporate law making authority among the various players, the "internal affairs" doctrine -according to which the internal affairs of a corporation are governed by the law of the state of incorporation -- is better thought of as contingent allocation of responsibility based on prudential considerations than any sort of iron dictate.

But even if a frontal Constitutional attack is weak, the underlying themes of "corporate federalism” or "cooperative federalism”"20 and states' rights have significant political and legal salience. It could, in other words, be an effective policy argument in the halls of Congress or the offices of the SEC. ${ }^{21}$ It could also provide the basis for an argument to courts when they interpret ambiguous federal legislation. ${ }^{22}$

In a line of cases beginning in 1995, the Supreme Court indicated that there exist limits to Congress's regulatory power under the Commerce Clause. U.S. v. Lopez, 511 U.S. 549 (1995) (gun free school zones act held unconstitutional); U.S. v. Morrison, 529 US 598 (2000) (civil damages provision in the Violence Against Women Act held unconstitutional). See, also, U.S. v. Jones, 529 U.S. 848 (2000) (interpreting federal law narrowly to avoid constitutional doubts whether Congress had exceeded its power under the Commerce Clause with regard to arson); Solid Waste Agency of Northern Cook County v. United States Army Corps of Engineers, 531 U.S. 159 (2001) (same with regard to migratory birds). Chemerinsky, §3.3.5. But this line of cases focuses entirely on the extent to which Congress can regulate non-commercial or non-economic activity under the Commerce Clause. There is no suggestion in the opinions, nor in subsequent case law, that the judicial skepticism would extend to indisputably commercial activity such as securities regulation or corporate governance.

The only genuine Commerce Clause issue that has recently arisen in corporate and securities law is the extent to which the Supremacy Clause or the (dormant) Commerce Clause preempts or precludes state regulation of takeovers. See, e.g., Edgar v. MITE Corp. 457 U.S. 624 (1982); CTS Corp. v. Dynamics Corp. of America, 481 U.S. 69 (1987). In CTS, in which the Supreme Court upheld Indiana's control share acquisition statute, the court held that the statute did not violate the commerce clause as it did not discriminate against interstate commerce, nor subject corporations to inconsistent standards. Neither case raises any question as to Congress's power to preempt state corporate law in the area of tender offers; only about whether Congress, in fact, intended to do so, and, in the case of CTS, whether, in the absence of any such intent, the Commerce Clause otherwise precluded the states from acting.

${ }^{20}$ While one might speak of a "corporate law federalism," it is more (descriptively) accurate to think of the distribution of corporate law-making as "decentralization.” Edward L. Rubin \& Malcom Feeley, Federalism: Some Notes on a National Neurosis, 41 UCLA L. REV. 903, 910-14 (1994). Whatever the general persuasiveness of Rubin and Feeley's view, in corporate law it is accurate: the extent of Congress's power under the Constitution to legislate in the corporate area is such that "our corporate law federalism" is a matter of an implicit or explicit decentralization driven by bureaucratic, political and legal process factors, as we discuss in greater detail in the text.

${ }^{21}$ Letter by Chief Justice Veasey, Delaware Supreme Court, to Alan Beller, Director of Division of Corporate Finance, Securities and Exchange Commission, Mar. 11, 2004 (expressing reservations about proposed SEC rule on shareholder nominations because rule would "intrude upon and may be in conflict with corporate internal affairs that are the province of state law.") (copy in possession of authors).

22 The U.S. Supreme Court has been solicitous of states’ primacy in corporate law. See, e.g., CTS Corp. v. Dynamics Corp. of America, 481 U.S. 69 (1987); Santa Fe Industries, Inc. v. Green, 430 U.S. 462, 97 S.Ct. 1292 , 51 L.Ed.2d 480 (1977). 
But, of course, the course of legislation is only partially determined by such policy and legal arguments. Interest groups matter too. Figures 1 and 2 provide a useful guide to those actors with sufficiently large interests to get involved politically. The constituents with an interest in corporate law are primarily managers and investors, with several other groups, such as lawyers and employees, taking a secondary interest in corporate law rules. To the extent that managers are opposed to a change in the law, organizations such as the Business Roundtable would lobby against it. To the extent that institutional investors are opposed, one would expect them to lobby as well. Moreover, Delaware is itself interested in limiting federal intrusions into corporate law and Delaware's interests are influentially represented. For example, during the $107^{\text {th }}$ Congress, when the Sarbanes-Oxley Act was enacted, both Delaware senators were on committees that considered the bill: Joseph Biden on the Judiciary Committee and Thomas Carper on the Banking, Housing \& Urban Affairs committee. ${ }^{23}$

Finally, the Constitution and internal Congressional rules make it easier to stop legislation than to enact it. To pass a law, legislation must ordinarily be approved by Congressional committees; be put on the agenda by the Congressional leadership; be approved by majorities in both houses of Congresses; either not be filibustered or favored by a supermajority of the Senate; and either be approved by the President or favored by veto-proof majorities in both houses. As a result, a determined minority of legislators can often block legislation favored by a majority.

To be sure, even with this build-in status quo bias, Delaware must keep the principal organized interest groups affected by Delaware corporate law reasonably satisfied in order to avoid federal intervention. For several reasons, however, we do not regard federal intervention due to interest group pressure as a major threat for Delaware.

First, "satisfied" in this context relates not only to the specific legal rules in force but more generally to a judgment of comparative institutional competence - namely, which lawmaking institution is likely to perform better over the long term. Even if managers and investors are dissatisfied with a particular substantive rule of Delaware law, there are a number of plausible reasons why they may nevertheless not push for federal intervention. First, they may believe that they will carry more relative weight in Delaware than in any of the alternative federal institutions, perhaps because employees or SEC bureaucrats will be more influential at the federal level. Second, Delaware may be more responsive to new developments, have greater expertise in applying rules, or otherwise be able to devise rules that are superior to those likely to emerge from federal actors. Third, it may be less costly to influence Delaware than Congress or the SEC. And fourth, a federal system may be viewed as a less risky forum because, for example, it is less likely to generate radical legislation or because it affords greater opportunities to opt-out of legislation (by changing corporate domiciles) than a monopolist federal regulator.

${ }^{23}$ [2001-2002] Cong. Index (CCH) 11,501-502 (Aug. 23, 2002). 
Second, even when Congress has enacted legislation otherwise trampling on states' right, it has historically taken special care not to intrude upon Delaware. For example, the Securities Litigation Uniform Standards Act, ${ }^{24}$ which in effect deprived state courts of jurisdiction over securities class actions for misrepresentations or deceit and eliminated the states' ability to apply their own securities laws on misrepresentations or deceit in class actions, contains the so-called "Delaware carve-out" ${ }^{25}$ which specifically exempts actions for misrepresentations based on the corporation law of a company's state of incorporation from its provisions. ${ }^{26}$ Similarly, the proposed Class Action Fairness Act, designed to assure that most class actions with a national class of plaintiffs are adjudicated in federal court, specifically excludes corporate law class actions arising under the law of the company's state of incorporation. ${ }^{27}$ Perhaps not coincidentally, Delaware's Senator Carper is one of six original sponsors (and one of a handful of Democratic supporters) of the Senate version of the act. For one reason or another, Delaware's corporate law seems to enjoy great respect on Capitol Hill. ${ }^{28}$

Most importantly, however, Delaware has strong incentives to keep investors and managers satisfied even apart from the possibility of federal intervention. Investors and managers control incorporation decisions of companies when they go public and decisions of existing public companies to reincorporate. As Delaware caters anyway to investors and managers in order to attract incorporations, keeping investors and managers sufficiently satisfied that they do not lobby for federal intervention should thus not require much additional effort or adjustment. ${ }^{29}$ Moreover, to the extent that particular investors and managers are dissatisfied, it is usually much easier for them to induce a particular firm to incorporate in a different state than to lobby for a change in federal law.

\footnotetext{
${ }^{24}$ Codified in section 16 (b) to (f) of the Securities Act. Technically, the act makes most securities class actions removable to federal court.

${ }^{25}$ See, e.g., Spehar v. Fuchs, 2003 U.S. Dist. LEXIS 10406, n. 4 (S.D.N.Y. 2003) (noting that Section 16(d) of the Securities Act is known as the "Delaware carve-out”).

${ }^{26}$ Section 16(d).

${ }^{27}$ Class Action Fairness Act, 2003 S. 274.2003 H.R. 1115.

${ }^{28}$ Similarly, Senator Biden has been able to block the enactment of a 1997 proposal by the National Bankruptcy Review Commission to eliminate state of incorporation as a venue for bankruptcy cases. See David Skeel, Bankruptcy Judges and Bankruptcy Venue: Some Thought on Delaware, 1 DEL. L. REV. 1, 44 (1998). Although Delaware derives some benefits from being a venue in major bankruptcy cases, these benefits pale in comparison to those from being the domicile of most publicly traded companies. See Marcel Kahan \& Ehud Kamar, The Myth of State Competition in Corporate Law, 55 STAN. L. REV. 67, 694 n. 50 (2002)

${ }^{29}$ To be sure, the relative power of investors and managers may differ from the incorporation and reincorporation contexts to the context of federal lobbying, thus providing some incentives for the group that is more powerful in the lobbying context to seek federal intervention. But the direction of that difference is unclear, unstable, hard to predict, and is likely to be small. Kahan \& Kamar, supra note 18, at 740-741, 743-745.
} 
A greater concern than federal intervention due to interest group pressure is the possibility that federal intervention will be triggered by a situation in which systemic change will be seen as generating a significant populist political payoff (a payoff unrelated to interest group pressure). ${ }^{30}$ Such situations can arise in times of crisis or scandal or due to political entrepreneurship. ${ }^{31}$

High profile scandals can shift the balance of power both in Congress and, derivatively, at the Securities and Exchange Commission, by triggering a deep, populist theme in American politics and energizing broad, loosely organized constituencies. The classic examples of large scale federal incursion into corporate law in response to crisis and scandal is the enactment of the 1933 Securities Act and the 1934 Securities Exchange Act, which created the SEC and, more recently, the enactment of the Sarbanes-Oxley Act and the changes in the stock exchange listing rules. Here, we had major scandals that coincided with the bursting of a stock market bubble that left investors licking their wounds and looking for someone to blame. ${ }^{32}$ Congressional hearings were held and there was a feeling that "something must be done.” Congress felt pressure to act, and act it did. ${ }^{33}$

The danger of a populist backlash against Delaware is aggravated by the lurking argument that Delaware lacks political legitimacy. Why should a small state - a "pigmy", as a leading proponent of a federal corporate law referred to it pejoratively ${ }^{34}$ - have so significant a law-making role for national corporate law and, in the process, derive huge profits? From the perspective of democratic theory, would it not make more sense if the members of Congress, elected by all U.S. citizens, made the law affecting corporations with national operations and shareholders? It is against this background lack of democratic legitimacy that populist appeals for federal intervention will be made and resonate. ${ }^{35}$

\footnotetext{
${ }^{30}$ For example, the press describes Eliot Spitzer's actions as populist. See, e.g., John Cassidy, The Investigation: How Eliot Spitzer Humbled Wall Street, THE NEW YoRKER, Apr. 7, 2003 at 54 ("Spitzer was well placed to launch a populist crusade”); Spitzer's Grandstand, WALL ST. J., MAR. 5, 2004, at A14 ("New York Attorney General Eliot Spitzer fancies himself as a populist hero for assailing Wall Street misdeeds ...”).

31 For examples from the history of U.S. regulation of business, see Mark Roe, STRONG MANAGERS, WEAK OWNERS (1994) Chapter 4.

${ }^{32}$ See also Stuart Banner, What Causes New Securities Regulation? 300 Years of Evidence, 75 WASH . U. L. Q. 849, 850 (1997) (most new regulations follow stock market crashes).

${ }^{33}$ See, e.g., Romano, supra note 12 (discussing how act is product of political entrepreneurship, rather than interest group lobbying); Headline Risk at the SEC, WALL ST. J., May 10, 2004, at A16 (accusing SEC to adopt cumbersome mutual fund regulations for their headline value).

${ }^{34}$ See Cary, supra note 18.

${ }^{35}$ See, e.g., Jonathan Chait, Rogue State: The Case Against Delaware, NEw REPUBLIC, Aug. 19, 2002 at 20; Triumph of the Pygmy State, THE ECONOMIST, Oct. 23, 2003 (questioning why the laws of state with .3\% of population governs more than half of public corporations); Cary, supra note 18.
} 
Alas for Delaware, it can do nothing to deprive Congress of its power to enact corporate laws and little to prevent crises, scandals, or the emergence of political entrepreneurs. What Delaware can do, however, is structure its law in a manner adapted to preserving its scope and reduce the likelihood that it will become the target of systemic change.

As we discuss in Part III, many traits of Delaware corporate law can be understood as adaptations to the institutional and political landscape in which Delaware, as the leading supplier of corporate law, must operate. This landscape includes Delaware's constitutional and political vulnerability to federal intervention and the strictures imposed by jurisdictional and conflict rules. Our claim is not that Delaware purposefully adopted these traits to serve its aims. We do not believe that the connection is that direct. Rather, the claim is that key patterns of Delaware corporate law making are consistent with the Delaware actors being sensitive to their institutional role and its limitations. Even if these pattern have not been purposefully adopted, the fact that they serve this function contributes to their survival.

Finally, we will argue in part IV that not every federal intervention into corporate law is against Delaware's interest. Because of the political constraints placed on Delaware by its desire to avoid systemic change, and because of the legal constraints imposed by jurisdictional and conflict rules, Delaware cannot effectively regulate certain types of misconduct. In these areas, which include much of traditional securities regulation, Delaware should have no major problem with federal regulation. To the contrary, Delaware may favor federal intervention to the extent that it makes the corporate law system as a whole less scandal prone and reduces the chances of a populist backlash against Delaware as principal regulator. Thus, the relationship between federal and state regulation in corporate law is, in our view, more symbiotic and less antagonistic than generally presumed. ${ }^{36}$

\section{Salient Traits of Delaware Corporate Law}

Delaware's corporate law has a number of salient and characteristic traits. These traits concern its style, the manner in which it is enforced, and its scope. In this Part, we explore Delaware corporate law's traits in six areas: the breadth of its judge-made law; its quasideterministic judge-made law; the making of its statutory law; its judiciary; its enforcement mechanism; and the overall scope of its corporate law. As we will explain in the next Part, all these traits can be seen as adaptations to the peculiar landscape in which Delaware, a tiny state that is the leading supplier of corporate law, must operate.

\section{A. The Breadth of Judge-Made Law}

\footnotetext{
${ }^{36}$ Cf. Roe, supra note 3 (focusing on the role of federal regulation as Delaware's competition); Bebchuk, supra note 18 (calling for replacement of state law by federal law); Cary, supra note 18 (same); Roberta Romano, Empowering Investors: A Market Approach to Securities Regulation, 107 YALE L. J. 2359 (1998) (calling for wholesale repeal of federal securities regulation and replacement by state law).
} 
The most noteworthy trait of Delaware's corporate law is the extent to which important and controversial legal rules are promulgated by the judiciary, rather than enacted by the legislature. In Delaware, judge-made law, to the virtual exclusion of statutory law, governs fundamental issues such as fiduciary duties of directors, officers, and controlling shareholders, the prerequisites for a derivative suit, and disclosure obligations. Even powers that the Delaware code explicitly accords to the board of directors are subject to a judicially created and interpreted duty not to use these powers for "inequitable purposes." 37 Thus, judge-made, rather than statutory, law governs issues such as:

- $\quad$ when directors are liable (the famous business judgment rule); ${ }^{38}$

- $\quad$ what counts as a self-interested transaction; ${ }^{39}$

- $\quad$ who is regarded as a controlling shareholder; ${ }^{40}$

- $\quad$ the scope of a controlling shareholder's obligations; ${ }^{41}$

- $\quad$ the legal test to determine the validity of a self-interested-transaction; ${ }^{42}$

- $\quad$ when a director is considered "independent;" 43

- $\quad$ the legal effect of approval of a transaction by independent directors or by disinterested shareholders; ${ }^{44}$

- what constitutes a "corporate opportunity"; 45

- $\quad$ the legal tests regulating takeover defenses; ${ }^{46}$

- $\quad$ when a board can take actions that interfere with shareholder franchise; ${ }^{47}$

- when a shareholder can institute a derivative suit without making a prior demand on the board; 48

\footnotetext{
${ }^{37}$ See, e.g., Schnell v. Chris-Craft Ind., 285 A.2d 437 (Del. 1971).

${ }^{38}$ See, e.g., Gagliardi v. TriFoods Internation, Inc., 683 A.2d 1049 (Del. Ch. 1996).

${ }^{39}$ See, e.g., Orman v. Cullman, 2002 Del. Ch. LEXIS 18.

${ }^{40}$ See, e.g., Kahn v. Lynch, 638 A.2d 1110 (Del. 1994).

${ }^{41}$ See, e.g., Sinclair Oil Corp. v. Levien, 280 A.2d 717 (Del. 1971).

${ }^{42}$ See, e.g., Marciano v. Nakash, 535 A.2d 400 (Del. 1987).

${ }^{43}$ See, e.g., Aronson v. Lewis, 473 A.2d 805 (Del. 1984).

${ }^{44}$ See, e.g., Kahn v. Lynch, 638 A.2d 1110 (Del. 1994).

${ }^{45}$ See, e.g., Broz v. Cellular Information Systems, Inc., 673 A.2d 148 (Del. 1996).

${ }^{46}$ See, e.g., Unocal Corp. v. Mesa Petroleum Co. 493 A.2d 946 (Del. 1985).

${ }^{47}$ See, e.g., Blasius Industries Inc. v. Atlas Corp., 564 A.2d 651 (Del. Ch. 1988).

${ }^{48}$ See, e.g., Aronson v. Lewis, 473 A.2d 805 (Del. 1984).
} 
- $\quad$ when shareholders lose their limited liability; ${ }^{49}$

- $\quad$ limitations on charitable giving; ${ }^{50}$

- $\quad$ the right of contestants to be reimbursed for expenses incurred in proxy contests; ${ }^{51}$ and

- $\quad$ when officers and directors are entitled to indemnification. ${ }^{52}$

Neither historic contingency nor the nature of the legal rules at issue fully explain this breadth of judge-made law. To be sure, the law of fiduciary duties has historically been developed by the judiciary. Nevertheless, Delaware's judge-made law is distinctive in a number of ways. First, Delaware, whose economic well-being depends on the franchise revenues it earns from public corporations, should be expected to pay significant attention to the way its law is generated. Other states, who do not derive significant economic benefits from chartering companies, may be affected by inertia and inattention with respect to the structure of their corporate laws. In Delaware, however, where franchise taxes account for $20 \%$ of the state budget, ${ }^{53}$ historical artifact cannot, by itself, explain why the legislature has not taken a more active role.

Second, even though fiduciary duty law has historically been judge-made, many states other than Delaware have statutorily revised portions of fiduciary duty law. For example, Indiana has a statute governing a board's fiduciary duties in a takeover contest; ${ }^{54}$ Idaho's statute defines "conflicting interest"; 55 California's statute defines "control”; ${ }^{66}$ Ohio's statute revises the burden of proof in shareholder lawsuits; ${ }^{57}$ Michigan's statute defines a special class of independent directors and accords them special rights in derivative proceedings; ${ }^{58}$ over 30 states passed statutes permitting a board to consider broader interests in discharging their fiduciary

${ }^{49}$ See, e.g., Mabon, Nugent \& Co. v. Texas American Energy Corp., 1988 Del. Ch. Lexis 11 (1988).

${ }^{50}$ See, e.g., Theodora Holding Corp. v. Henderson, 257 A.2d 398 (Del. Ch. 1969); Kahn v. Sullivan, 594 A.2d 48 (Del. 1991).

${ }^{51}$ See, e.g., Hibbert v. Hollywood Park, Inc., 457 A.2d 339 (Del. 1983).

${ }^{52}$ See id.

${ }^{53}$ Roberta Romano, Law as a Product: Some Pieces of the Incorporation Puzzle, 1 J.L. ECON. \& ORG. 225 (1985)

5435 Ind. Code Ann. §23-1-35-1.

${ }^{55}$ Id. Code $§ 30-1-860$.

${ }^{56}$ Cal. Corporations Code, Sec. 160.

${ }^{57}$ Ohio Code 1701.59.

${ }^{58}$ Mich. Comp. Laws, Sec. 50.1495. 
duties; ${ }^{59}$ and the Revised Model Business Corporation Act, adopted by over 20 states, codified the standards of conduct for liability of directors ${ }^{60}$ and the standards for commencement and dismissal of derivative suits. ${ }^{61}$ Delaware law, by contrast, contains no equivalent statutory provisions. Thus, corporate law is judge-made in Delaware to a greater extent than in most other states.

Third, the Delaware judiciary has taken the lead in expanding the breadth of judge-made law beyond its traditional domain. Judicial decisions in Delaware have thus created novel doctrines regulating actions by a board of directors that are taken for inequitable purposes ${ }^{62}$ or that are intended to interfere with shareholder franchise ${ }^{63}$ and have minted a new fiduciary duty of disclosure. ${ }^{64}$ While these new doctrines can all be justified as complementing traditional fiduciary duties, they nevertheless represent an extension of the historic breadth of these duties and have been rejected by other jurisdictions. ${ }^{65}$ At a minimum, these doctrines show the great comfort on the part of Delaware's judiciary, and great tolerance on the part of its legislature, for having the courts expand the scope of judge-made law to address novel problems, rather than waiting for the legislature to act.

Fourth, the Delaware supreme court has shown a certain degree of discomfort with, perhaps even hostility to, legislative intrusions in its domain. There are numerous examples of this tendency.

- $\quad$ Section 262(h) of the Delaware General Corporation Law (DGCL) explicitly provides that, in an appraisal proceeding, the fair value of shares is to be assessed "exclusive of any element of value arising from any accomplishment or expectation of the merger." Yet, in Weinberger v. UOP, the Delaware supreme court read this "to be a very narrow

\footnotetext{
${ }^{59}$ Guhan Subramanian, The Influence of Antitakeover Statutes on Incorporation Choice: Evidence on the “Race” Debate and Antitakeover Overreaching, 150 U. PA. L. REV. 1795 (2002).

${ }^{60}$ Rev. Model. Bus. Corp. Act, $§ \S 8.30$ and 8.31[8.60-8.63] The Comment notes that these rules "spell[] out a practical working definition of 'conflicting interest' [and are designed to create] "bright line specificity and predictability”. 2 Model Bus. Corp. Act Annotated §§8.60-8.63 Introductory Comment at 8-386 (3rd ed. 1996).

${ }^{61}$ Rev. Model. Bus. Corp. Act, $§ \S 7.40-7.46$

${ }^{62}$ Schnell, 285 A.2d at 437.

${ }^{63}$ Blasius, 564 A.2d at 651; MM Cos. v. Liquid Audio, Inc., 813 A.2d 1118 (Del. 2003).

${ }^{64}$ Block et al., supra note 11 , at 499-500.

${ }^{65}$ See, e.g., Invacare Corp. v. Healthdyne Tech., Inc., 968 F.Supp. 1578, 1581 (N.D. Ga. 1997) (declining to follow Blasius); Solfanelli v. Aminwaring, 1992 U.S.Dist. LEXIS 18883, at *13 (E.D.Pa. 1992) (no duty of disclosure under Pennsylvania law). Most states have not had occasion to determine whether they adopt these new doctrines.
} 
exception to the appraisal process designed to eliminate pro forma data and projections of a speculative variety."66

- $\quad$ Section 144(a)(1) and (2) of the DGCL provides that a self-dealing transaction shall not be voidable solely for this reason if it is approved, after full disclosure by "a majority of the disinterested directors [or] in good faith by vote of the shareholders." ${ }^{67}$ Yet, in Marciano $v$. Nakash, the Delaware supreme court read this to require "approval by fully informed disinterested directors under section 144(a)(1), or disinterested stockholders under section 144(a)(2)," in order to insulate a self-dealing transaction from attack. ${ }^{68}$

- $\quad$ Section 157(b) of the DGCL (rights and options respecting stock) provides that "[i]n the absence of actual fraud in the transaction, the judgment of the directors as to the consideration for the issuance of such rights or options and the sufficiency thereof shall be conclusive.” Yet, in numerous compensation cases, the Delaware supreme court read this to permit review of grants of options (even to non-directors) under a waste standard, not just the statutorily decreed "actual fraud" standard. ${ }^{69}$

- $\quad$ Section 251(c) of the DGCL was amended in 1998 to permit a merger agreement to expressly stipulate that it must "be submitted to the stockholders whether or not the board of directors determines at any time subsequent to declaring its advisability that the agreement is no longer advisable and recommends that the stockholders reject it." Yet, just last year, the Delaware supreme court in NCS v. Omnicare ${ }^{70}$ held that this very stipulation constituted a per se breach of fiduciary duty by the board because a controlling shareholder concurrently agreed to vote in favor of the merger.

Fifth, in Delaware, legislative overturning of judge-made corporate law is practically unheard of. $^{71}$ In the modern era, there has been only one significant instance of such

${ }^{66} 457$ A.2d 701, 713 (1983).

${ }^{67}$ (emphasis added).

${ }^{68} 535$ A.2d 400, 405, n. 3 (1987) (emphasis added).

${ }^{69}$ See, e.g., Michelson v. Duncan, 407 A.2d 211, 223 (Del. 1979) (“Section 157 was intended to protect directors' business judgment in consideration inuring to the corporation in exchange for creating and issuing stock options ... [W] do not read section 157 as intended to erect a legal barrier to any claim for relief as to an alleged gift or waste of corporate assets in the issuance of stock options where the claim asserted is one of absolute failure of consideration.”); see also Zupnick v. Goizueta, 698 A.2d 384 (Del. Ch. 1997).

${ }^{70} 818$ A.2d 914 (Del. 2003).

${ }^{71}$ In other areas and other states, the legislature does act to overturn judge-made law. See, e.g., 142nd General Assembly of Delaware, House Bill 309 (overturning Delaware supreme court precedents on searches and seizures); 140th General Assembly of Delaware, HS 1 (overturning Delaware supreme court precedents on statutes of limitations); 140th General Assembly of Delaware, HB 249 (overturning Delaware supreme court precedents on 
overturning, and this instance represents the classic exception that proves the rule. In 1985, the Delaware supreme court, in Smith v. Van Gorkom, ${ }^{72}$ greatly expanded the risk that directors would be held liable for breaches of their duty of care. The decision, described by leading commentators as "shocking", 73 "one of the worst decisions in the history of corporate law"74 and the like, led to the enactment of Section 102(b)(7). By permitting a company to opt-out of personal liability for non-intentional breaches of the duty of care, Section 102(b)(7) took the sting out of the Van Gorkom decision. The enactment of Section 102(b)(7) was widely supported by members of the bar, Delaware was quickly followed by numerous states that enacted similar provisions, and charter amendments availing themselves of the opportunity to opt-out enjoy wide shareholder support. ${ }^{75}$ But for this egregious instance, we are not aware of any significant corporate law decision in Delaware that has been legislatively overruled. By contrast, in the comparatively narrow field of insider trading, at least five decisions by the United States Supreme Court or federal circuit courts have been overturned by Congress or the Securities and Exchange Commission. ${ }^{76}$

\section{B. The Quasi- Deterministic Style of Delaware’s Judge-Made Law.}

insurance law); Eric Robinson, John C. Coates IV \& Mitchell S. Presser, State Takeover Statutes: A Fifty-State Survey (1989) (noting that Colorado, Georgia, Indiana, New Jersey, New York, and Virginia passed statutes overturning court decisions that had invalidated poison pill plans).

72488 A2d 858 (1985).

${ }^{73}$ William T. Allen \& Reinier Kraakman, COMMENTARIES AND CASES ON THE LAW OF Business ORGANIZATION (2003) at 254.

${ }^{74}$ Daniel Fischel, The Business Judgement Rule and the Trans Union Case, 40 Bus. LAW. 1437, 1455 (1985).

${ }^{75}$ Roberta Romano, Corporate Governance in the Aftermath of the Insurance Crisis, 39 EMORY L. J. 1155

${ }^{76}$ See Securities Exchange Act, Section 20A(a) (establishing private right of action based on contemporaneous trading) overturning Moss v. Morgan Stanley, 719 F.2d 5 (2nd Cir. 1983) (no private right of action where violation is premised on misappropriation theory); Securities Exchange Act, Section 20(d) (extending insider trading prohibition to derivatives where trading in underlying security is not permitted) overturning Laventhall v. General Dynamics Corp., 704 F.2d 407 (8th Cir. 1983), cert. denied 464 U.S. 846 (holding that insider owes no duty to abstain from trading to optionholder); Securities Exchange Act Rule 10b5-1 (establishing "possession” test for insider trading) overturning U.S. v. Smith, 155 F.3d 1051, 1066-69 (9th Cir. 1998) (adopting "use” test); Securities Exchange Act Rule 10b5-2 (establishing presumptive duty of trust and confidence among family members) overturning U.S. v. Chestman, 903 F.2d 75 (2d Cir. 1990) (holding that family members of insiders owe no duty to family, corporation, or shareholders that obligates them to abstain from trading); Securities Exchange Act Rule 14e-3 (prohibiting trading based on information related to tender offer received directly or indirectly from bidder) overturning effect of Chiarella v. U.S., 445 U.S. 222 (1980) (holding that employee of printer working for bidder had no relation with target shareholders that obligated employee to abstain from trading) 
Beyond the breadth of judge-made law, the mode of judge-made law is noteworthy. As several commentators have recently emphasized, judge-made Delaware law eschews hard rules in favor of flexible and highly fact-intensive standards. ${ }^{77}$ This results in an extraordinarily high degree of flexibility. A typical Delaware opinion reads as if the specific facts, combined with long-standing and universally accepted fiduciary principles, clearly dictate the outcome of the case. This permits Delaware law to respond to new problems or to revise the way it is dealing with old problems without openly admitting that the judges made new law or changed old law. ${ }^{78}$

Indeed, the Delaware Supreme Court rarely overrules its own precedents. ${ }^{79}$ Instead, it tends to justify a ruling that is in tension with precedent (of which there have been a fair share) by explaining that general-sounding rules announced in earlier cases apply only to a much narrower set of circumstances ${ }^{80}$ or attributing any misunderstanding by lawyers or lower court

${ }^{77}$ See, e.g., Edward B. Rock, Saints and Sinners: How Does Delaware Corporate Law Work?, 44 UCLA L. REV. 1009 (1997); Ehud Kamar, A Regulatory Competition Theory of Indeterminacy in Corporate Law, 98 ColuM. L. REV. 1908 (1998); Marcel Kahan \& Ehud Kamar, Price Discrimination in the Market for Corporate Law, 86 CORNELL L. REV. 1205. 1233-40 (2001).

${ }^{78}$ Cf. Lucian A. Bebchuk \& Assaf Hamdani, Vigorous Race or Leisurely Walk: Reconsidering the Debate on State Competition over Corporate Charters, 112 YALE L. J. 553, 603 (2002) (arguing that indeterminacy helps Delaware fend-off federal intervention). Bebchuk and Hamdani view indeterminacy as helping Delaware hide the extent to which its law favors managers and the extent to which it changes the law to respond to the fear of federal intervention. By contrast, we view indeterminacy as reinforcing the technocratic gloss of judge-made law.

${ }^{79}$ A Lexis search in the Delaware Supreme Court database using the search term "overrule” has revealed no instance in the last 20 years where the supreme court overruled its own corporate law precedent. It did reveal, however, 10 decisions in other areas where the supreme court overruled its own precedent. See, e.g., Public Water Supply v. DiPasquale, 735 A.2d 378 (Del. 1999) (overruling 1994 decision on judicial review of administrative agencies).

${ }^{80}$ Compare, e.g.., Unocal Corp. v. Mesa Petroleum, 493 A.2d 946 (Del. 1985) (noting that directors may consider "the impact [of a takeover bid] on 'constituencies' other than shareholders (i.e., creditors, customers, employees, and perhaps even the community generally)" in resisting a bid) with Revlon Inc. v. MacAndrews \& Forbes, 506 A.2d 173 (Del. 1986) (faulting directors for taking account adverse impact of bid on noteholders, whose rights "were fixed by contract" and therefore "required no further protection" and explaining that board may consider other constituencies only if "there are rationally related benefits accruing to stockholders."); In re Tri-Star Pictures, Inc., Litig. 634, A.2d 319, 333 (Del. 1993) ("In Delaware existing law and policy have evolved into a virtual per se rule of damages for breach of the fiduciary duty of disclosure.") with Loudon v. Archer-DanielsMidland Co., 700 A.2d 135, 141 (Del. 1997) (“Tri-Star stands only for the narrow proposition that, where directors have breached their disclosure duties in a corporate transaction that has in turn caused impairment to the economic or voting rights of stockholders, there must at least be an award of nominal damages.”). 
judges to their failure to read supreme court precedent carefully. ${ }^{81}$ Similarly, supreme court judges in Delaware rarely dissent. ${ }^{82}$

Consistent with the presentation of Delaware law as a body of stable, clear, uncontroversial and easy-to-follow standards laid down in a body of prior precedent, the court reacts harshly when directors' actions fail to measure up. In such instances, judicial opinions often highlight these failures in preachy, moralistic terms. ${ }^{83}$ Deficiencies in the conduct of directors - whether because of ill-will, lack of backbone, or at the least incompetence - are presented as constituting a failure for which punishment is warranted (and not, say, to a reasonable, good-faith interpretation of what prior judicial decisions require), and directors are regularly pilloried for such failures by Delaware's supreme court. ${ }^{84}$

\section{The Making of Delaware's Statutory Law}

Although formally adopted by the legislature, Delaware's elected representatives have no significant role in the crafting of Delaware's statutory corporate law. It is the Council of the

\footnotetext{
${ }^{81}$ Compare, e.g.., Weinberger v. UOP, 457 A.2d 701 (Del. 1983) (in freezeout merger, plaintiff’s "monetary remedy ordinarily should be confined to ... appraisal”) with Rabkin v. Phillip A. Hunt Chemical Corp., 498 A.2d 1099, 1104 (Del. 1985) (reversing chancery court applying that principle and faulting it for adopting "narrow interpretation of Weinberger [that] would render meaningless our extensive discussion of fair dealing found in that opinion”); Paramount Communications v. Time Inc., 571 A.2d 1140 (Del. 1989) (noting holding by chancery court that Time-Warner merger agreement did not result in change of control because control remained in fluid aggregation of unaffiliated shareholders, but explicitly premising its holding that no change of control occurred on different ground, i.e. the absence of a break-up) with Paramount Communications Inc. v. QVC Networks Inc., 637 A.2d 34 (Del. 1994) (endorsing rationale offered by the chancery court in Time and noting that defendants "misread" earlier cases and "totally ignore” portions of their language); see also Kahn v. Lynch, 638 A.2d 1110 (Del. 1994) (resolving conflict in chancery court as to effect of approval by special committee by noting that "definitive answer" can be found in earlier supreme court opinions); Mills Acquisition v. Macmillan Inc., 559 A.2d 1261, 1283 (Del. 1988) ("Following Revlon, there appeared to be a degree of "scholarly" debate about the particular fiduciary duty that had been breached in that case, i.e. the duty of care or the duty of loyalty. In Ivanhoe, 535 A.2d at 1345, we made it abundantly clear that both duties were involved in Revlon, and that both had been breached." (emphasis added)).

${ }^{82}$ David A. Skeel, Jr., The Unanimity Norm in Delaware Corporate Law, 83 Va. L. Rev. 127, 132 (1997) (noting low rate of dissents, in absolute terms and compared to other states).

${ }^{83}$ See generally Rock, supra note 77.

84559 A.2d at 1279 (describing board of Macmillan as “torpid, if not supine”); 498 A.2d at 1106 (noting that special board committee of Hunt directors engaged in a "quick surrender" when faced with a squeeze-out offer by Hunt's controlling shareholder); 637 A.2d at 48 (stating that directors of Paramount "remained prisoners of their own misconceptions”); Kahn v. Tremont, 694 A.2d 422 (Del. 1997) (noting that disinterested directors “abdicated their responsibility” and “default[ed] on their obligation to remain fully informed”); Rock, supra note 77 (detailing other instances in which Delaware courts castigated actions by directors).
} 
Corporation Law Section of the Delaware Bar Association, rather than a legislative committee, ${ }^{85}$ that prepares drafts of proposed amendments to the General Corporation Law. These proposals are often instigated by lawyers who have encountered an ambiguity or a technical problem in the statute that they want to have clarified or corrected. After the Corporate Law Section has developed a proposal, it is submitted to the legislature. Delaware's legislature then typically adopts the proposed amendments. Neither a legislative committee nor the legislature as a body changes the proposal or debates its merits and the vote on the proposed amendment tends to be

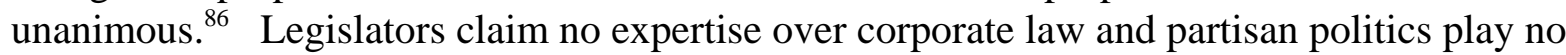
role in its formation. ${ }^{87}$

Even within the Delaware bar, proposed amendments hardly ever generate controversy. ${ }^{88}$ One reason is that the Corporate Law Section endeavors to make the necessary compromises to reach a consensus. For example, a significant amount of bargaining took place on the Council over the precise scope of Section 102(b)(7) in order to generate an unanimous proposal for the legislature to act upon. ${ }^{89}$

The ultimate reason for the lack of controversy over statutory amendments, however, is that, although Delaware regularly revises its corporate law, most amendments address minor or technical issues. Consider, for example, the 1999 amendments to the DGCL which made

\footnotetext{
${ }^{85}$ The Delaware Senate has 26 committees, the House has 28 committees. See www.legis.state.de.us/Legislature.nsf/?Opendatabase.

${ }^{86}$ This is not the uniform mode for legislation in Delaware. In other areas, bills are amended in the legislative process, pass with dissent, or are defeated. See, e.g., 142nd General Assembly of Delaware, House Bill 15 (showing several proposed amendments to bill on smoking regulation and eventual defeat in the Senate), available at

http://www.legis.state.de.us/Legislature.nsf/fsLIS?openframeset\&Frame=Main\&Src=/LIS/LIS142.NSF/Home?Open form; 142nd General Assembly of Delaware, House Bill 24 (showing Senate defeat on bill clarifying crime of offering false instrument for filing), available at http://www.legis.state.de.us/Legislature.nsf/fsLIS?openframeset\&Frame=Main\&Src=/LIS/LIS142.NSF/Home?Open form; 142nd General Assembly of Delaware, House Bill 182 (showing divided committee report on and several amendments to bill medical malpractice), available at http://www.legis.state.de.us/Legislature.nsf/fsLIS?openframeset\&Frame=Main\&Src=/LIS/LIS142.NSF/Home?Open form. Nor is this the uniform mode for corporate law legislation in states other than Delaware. See Kahan \& Kamar, supra note 28, at 732 (describing significant political controversy over section of New York law imposing personal liability on large shareholders for wage claims); Andrew Ross Sorkin, Michigan Senate Approves Change in Takeover Laws, N.Y. TimES, Sep. 19, 2003, at C4 (noting that bill protecting Taubman family to block a takeover of its shopping mall company by Simon Property Group was passed by 24-14 after amendment to bill that would have enabled bidder to continue takeover effort was defeated 19-19).

${ }^{87}$ Curtis Alva, Delaware and the Market for Corporate Charters: History and Agency, 15 DEL. J. CoRP. L. 885 (1990).

${ }^{88}$ Id. at 914.

${ }^{89}$ Id. 914 - 915.
} 
changes to ten sections. ${ }^{90}$ Six of the changes concern only nonstock corporations ${ }^{91}$ or deal with the conversion of a corporations into a domestic LLC, a limited partnership, or a business trust (with unanimous shareholder approval), and vice versa. ${ }^{92}$ The remaining four amendments address the following:

- Section 102(a) (name of corporations) was changed to provide that punctuation in terms such as "Ltd." was optional and that foreign terms designating corporate existence are acceptable as part of the name.

- Section 202 (transfer restrictions) was changed to clarify that restrictions may the placed on the amount of stock owned by any person, that a restriction may obligate a holder to sell restricted securities or provide for an automatic sale, and that restrictions imposed to qualify as a REIT are presumed to be reasonable.

- Section 251(g) (mergers with wholly-owned subsidiaries to create a holding company) was changed to clarify that the directors of the surviving company may be changed without vote by the shareholders of the holding company.

- Section 253 (short-form merger) was changed to clarify that the $90 \%$ ownership prerequisite for short-form mergers applies only to classes of outstanding shares that would, but for that section, be entitled to vote on the merger.

Thus, none of the 1999 amendments relate to corporate governance, fiduciary duties, or other core issues of corporate law and none could even remotely be anticipated to generate public debate or controversy. Although statutory amendments occasionally venture somewhat further

901999 Delaware Laws Ch. 123 (S.B. 137).

${ }^{91}$ Section 170 (dividends) was changed to clarify that nonstock corporations can declare dividends whether they for pro profit or not for profit. Section 242 (charter amendment) was modified to eliminate the requirement of two meetings by the governing body of a nonstock corporation to adopt a charter amendment. Section 255 (merger of nonstock corporations) lowers the approval threshold from two-thirds to a majority of members, thus conforming to the threshold for stock corporations.

${ }^{92}$ A new sections 266 permits a conversion by a corporation, a new section 265 permits a conversion into a corporation, and amendments to section 391 provide for fees for these conversions. 
afield from the technical, ${ }^{93}$ the 1999 amendments typify Delaware's legislative changes to its corporation law. ${ }^{94}$

\section{Distinctive Features of Delaware's Judiciary}

Delaware's judiciary, the principal generator and, as discussed below, enforcer of this distinctive law, is itself peculiar in several respects. First, as noted above, Delaware is the only state that has a specialized corporate trial court, the court of chancery, which decides cases without juries. ${ }^{95}$ Usually, several of the five supreme courts judges (at present, three) are former members of the chancery court. Thus, both on the trial and the appeals court level, corporate cases are decided by a specialized judiciary.

Second, compared both to judges in other states and to federal judges, Delaware's judiciary is non-politicized. ${ }^{96}$ Delaware is one of only eight states where judges are selected based on merit by a nominating commissions and face no elections. ${ }^{97}$ In addition, Delaware's constitution mandates a partisan balance in the supreme court and the overall judiciary. ${ }^{98}$

To be sure, unlike federal judges, Delaware judges serve a limited term. But just as initial appointment decisions, reappointment decisions are non-politicized. The only modern instance where a Delaware chancery or supreme court judge who wanted to get reappointed failed to be involves Justice Andrew Moore. The reason for this failure, however, is unrelated to his politics or his jurisprudence. Rather, Justice Moore, while praised for his intellectual

${ }^{93}$ For example, in a 1998 amendment, Section 251(c) was changed so that the merger agreement could require that the agreement be submitted to the stockholders whether or not the board of directors determines at any time subsequent to declaring its advisability that the agreement is no longer advisable and recommends that the stockholders reject it. See 1998 Delaware Laws Ch. 339 (S.B. 311). Of course, under federal law and Delaware fiduciary duty law, the directors would have to inform shareholders of their revised views and of the basis for these views. Moreover, the Delaware supreme court has held that directors violate their fiduciary duties by including such a requirement in the merger agreement when shareholders lack the effective ability to block the merger in the shareholder vote. See NCS, 818 A.2d at 914. This holding greatly limits the practical significance of the amendment.

${ }^{94}$ By contrast, laws in other states address more substantive issues. See, e.g., Subramanian, supra note 59, at 1857 - 1866 (describing severe anti-takeover statutes enacted by several states).

${ }^{95}$ Kahan \& Kamar, supra note 28, at 708-715.

${ }^{96}$ See also Skeel, supra note 82, at 134 (describing judicial appointment process as apolitical).

97 The Lawyers Almanac J-1 (2002)

${ }^{98}$ Del. Const art. IV, §3. 
prowess, is said to have lost favor among the corporate bar because he was perceived as "arrogant, acerbic, sanctimonious and upbraiding." 99

Finally, to a greater extent than is typical for members of the judiciary, Delaware judges propagate their vision outside the court room. Delaware judges publish an extraordinary amount of extra-judicial writing. ${ }^{100}$ Members of Delaware's judiciary are also regular participants in professional meetings, attend academic conferences, and give lectures to corporate directors. ${ }^{101}$

${ }^{99}$ See Karen Donovan, Shareholders' Advocates Protest Justice’s Removal, NATL. L. J., June 6, 1994, at B1; see also John Close, Justice Denied in Delaware, AMER. LAW., July/Aug. 1994, at 23 (noting that Justice Moore, the author of a string of seminal opinions, was prone to hand out "harsh chastisement of attorneys", "projected a sense of arrogance” and engaged in "ad hominem” questioning during oral argument).

100 The following is an incomplete list of such writings by current (and very recently retired) members of the Delaware supreme court and chancery court: William T. Allen, Jack B. Jacobs and Leo E. Strine, Jr, The Great Takeover Debate: A Meditation on Bridging the Conceptual Divide, 69 U. CHI. L. REV. 1067 (2002); William T. Allen, Jack B. Jacobs \& Leo E. Strine, Jr., Realigning the Standard of Review of Director Due Care with Delaware Public Policy: A Critique of Van Gorkom and its Progeny as a Standard of Review Problem, 96 Nw. U.L. REV. 449 (2002); William B. Chandler III and Leo E. Strine, Jr., The New Federalism of the American Corporate Governance System: Preliminary Reflections of Two Residents of One Small State, 152 U. PA. L. REV. 953 (2003); William B. Chandler III, On the Instructiveness of Insiders, Independents, and Institutional Investors, 67 U. CIN. L. REV. 1083 (1999); Randy J. Holland , State Jury Trials and Federalism: Constitutionalizing Common Law Concepts, 38 VAL. U.L. ReV. 373 (2004); Randy J. Holland \& David A. Skeel, Jr., Deciding Cases without Controversy, 5 DEL. L. REV. 115 (2002); Randy J. Holland \& Cynthia Gray, Judicial Discipline: Independence with Accountability, 5 WID. L. SYMP. J. 117 (2000); Randy J. Holland , State Constitutions: Purpose and Function, 69 TEMPLE L. REV. 989 (1996); Leo E. Strine, Jr., The Inescapably Empirical Foundations of the Common Law of Corporations, 27 DEL. J. CORP. L. 499 (2002); Leo E. Strine, Jr., The Social Responsibility of Boards of Directors and Stockholders in Change of Control Transactions: Is There Any "There” There?, 75 S. CAL. L. REV. 1169 (2002); Leo Strine, Jr., Delaware's Corporate-Law System: Is Corporate America Buying an Exquisite Jewel or a Diamond in the Rough? A Response to Kahan \& Kamar's Price Discrimination in the Market for Corporate Law, 86 CORNELl L. REV. 1257 (2001); E. Norman Veasey, Access to Justice: The Social Responsibility of Lawyers: Reflections on Key Issues of the Professional Responsibilities of Corporate Lawyers in the Twenty-First Century, 12 WASH. U. J.L. \& POL'Y 1 (2003); E. Norman Veasey, Robert S. Marx Lecture: Corporate Governance and Ethics in a Post Enron/Worldcom Environment, 72 U. CIN. L. REV. 731 (2003); E. Norman Veasey, State-Federal Tension in Corporate Governance and the Professional Responsibilities of Advisors, 28 Iowa J. Corp. L. 441 (2003); E. Norman Veasey, Views from the Bench: Musings on the Dynamics of Corporate Governance Issues, Director Liability Concerns, Corporate Control Transactions, Ethics and Federalism, 152 U. PA. L. REV. 1007 (2003); E. Norman Veasey, Policy and Legal Overview of Best Corporate Governance Principles, 56 SMU L. REV. 2135 (2003); E. Norman Veasey, Ethics 2000: Thoughts and Comments on Key Issues of Professional Responsibility in the Twenty-First Century, 5 DEL. L. REV. 1 (2002); E. Norman Veasey, The Ethical and Professional Responsibilities of the Lawyer for the Corporation in Responding to Fraudulent Conduct by Corporate Officers or Agents, 70 TEnN. L. REV. 1 (2002); E. Norman Veasey, Law and Fact in Judicial Review of Corporate Transactions, 10 U. MiAmi BuS. L. REV. 1 (2002); E. Norman Veasey, Should Corporation Law Inform Aspirations for Good Corporate Governance Practices -- or Vice Versa? , 149 U. PA. L. REV. 2179 (2001); E. Norman Veasey, The Roles of the Delaware Courts in Merger and Acquisition Litigation, 26 DEL. J. CORP. L. 849 (2001); E. Norman Veasey, The Many Facets of Judicial Independence Diamond, 20 QuiNNIPIAC L. REV. 779 (2001); E. Norman Veasey; An Economic Rationale for Judicial Decision-making in Corporate Law, 1 DEL. L. REV. 169 (1998).

${ }^{101}$ Interestingly, while the Delaware Chancery Court does not keep track systematically of chancellors' speeches or public appearances, the SEC provides a website with links to speeches and public statements of commissioners and staff. See http://www.sec.gov/news/speech.shtml. 
Thus, for example, Delaware judges regularly appear at the annual Tulane Corporate Law Institute: at the 2004 conference, Justices Veasey, Steele and Jacobs from the Delaware supreme court and Vice-Chancellor Strine from the chancery court were all present. ${ }^{102}$

\section{E. The Reliance on Private Enforcement}

Another notable trait of Delaware's corporate law is that it is enforced exclusively through private lawsuits. Delaware has no regulatory agency that enforces its corporate law; the state does not enforce corporate norms through criminal proceedings; and even though the Attorney General has some civil enforcement powers with respect to for-profit corporations, ${ }^{103}$ these powers are virtually never exercised. ${ }^{104}$

In striking contrast to this lack of public enforcement, Delaware has taken great care in developing a first-rate system for private enforcement. It is the only state in the nation that has a specialized corporate court, the court of chancery. The chancery court is well-funded, enjoys wide respect, resolves disputes speedily, and probably accounts for the fact that Delaware's overall court system is ranked first among all states. ${ }^{105}$ If needed, appeals from the chancery court are heard by the Delaware supreme court quickly and decided instantaneously after oral argument. Moreover, Delaware is at pains to assure that the chancery court has the personal jurisdiction that it needs in order to resolve the corporate disputes involving Delaware corporations. Thus, when the U.S. Supreme Court ${ }^{106}$ invalidated the statutory basis for Delaware's personal jurisdiction as inconsistent with due process, thereby threatening the ability of the chancery court to resolve corporate disputes, Delaware passed a new statute within 13 days establishing a different statutory basis for its jurisdiction over corporate directors. ${ }^{107}$ More recently, in light of the trend by public corporations to have only few officers serve on its board of directors, Delaware expanded its personal jurisdiction statute to include a corporation's senior

102 Indeed, the brochure promises benefits including the opportunity to "learn from and interact with members of the Delaware Supreme Court and Court of Chancery.” Brochure, Sixteenth Annual Corporate Law Institute (available on line at: http://www.law.tulane.edu/cdo/inst/2004CorpLawInst.pdf).

${ }^{103}$ DGCL, §124(3), 284

${ }^{104}$ In a search in Westlaw’s Delaware Business Organization Case Law file, we found 3 cases involving charitable corporations in which the Attorney General took some action. Otherwise, the Attorney General appeared in corporate disputes only as defendant in cases challenging the constitutionality of Delaware's anti-takeover law.

${ }^{105}$ Kahan \& Kamar, supra note 28, at 708.

106 Shaffer v. Heitner, 433 U.S. 186 (1977) (holding that Delaware’s quasi-in-rem statute was not a valid basis for its exercise of jurisdiction over directors of Delaware corporations).

${ }^{107}$ See Kahan \& Kamar, supra note 28, at n. 117. 
or most highly compensated officers, whether or not they are members of the board of directors. ${ }^{108}$

This focus on private enforcement is distinctive both from the international and the national perspective. Internationally, corporate law rules are to a large extent publicly enforced. Public and quasi-public enforcement agents include the securities regulators of various countries; stock exchanges; the Panel on Takeovers and Mergers which enforces the U.K. City Code on Takeovers and Mergers; and prosecutors which, in Continental Europe, bring criminal proceedings against misbehavior by corporate executives, including actions that would be regarded in the U.S. as, at most, civil breaches of fiduciary duties. ${ }^{109}$ Within the United States, corporate law rules adopted by the stock exchanges or through the federal securities laws are enforced publicly either on an exclusive basis or concurrent with private enforcement. ${ }^{110}$

To be sure, other states are not necessarily more active than Delaware is to enforce corporate laws publicly. But none of the other states has any significant stake in its corporate law and none of the other states has developed sophisticated structures for the private enforcement of its corporate laws equivalent to Delaware's. ${ }^{111}$ Moreover, at least some states other than Delaware publicly prosecute corporate misconduct. Recently, for example, Dennis Kozlowski, the CEO, and two other officers of Tyco International, were charged with grand larceny and violations of the general business law by the Manhattan District Attorney for looting the company through excessive compensation or taking unauthorized loans - classic self-dealing transaction by a corporate fiduciary. ${ }^{112}$ And, with a federal investigation pending, Oklahoma's Attorney General filed criminal charges against former WorldCom CEO Ebbers and five others

${ }^{108}$ See SEC. REG. \& L. RPTR., Aug. 11, 2003, at 1331, 1333.

${ }^{109}$ For example, several sections of the German Aktienrecht and U.K. company law imposes criminal penalties and fines for misconduct. See, e.g., Aktienrecht, §399 (false statements), §404 (violation of duty of confidentiality); Company Act 1985, §342 (criminalizing the extension of loans to directors in violation of Company Act). For a particularly high profile and dramatic example, see the current criminal prosecution of Josef Ackermann, CEO of Deutsche Bank, over his approval as a director of Mannesmann of a bonus to Mannesmann's $\mathrm{CEO}$ at the conclusion of the control battle with Vodafone. Mark Landler, Banker Faces German Court Over Pay Issue, NEW YoRK TIMES, January 20, 2004 at C1; Marcus Walker, After Huge Merger, German CEO Faces Trial over Payout, WALl ST. J., Nov. 6, 2003, at A1; see also Santander Chairman Ordered to Stand Trial, WALL ST. J., Apr. 28. 2004, at C2 (reporting that three executives of Spanish bank were being tried for arranging generous severance packages for bank’s former executives).

${ }^{110}$ See Securities Exchange Act, Sec. 21 (empowering SEC to investigate violations of and enforce provisions of Securities Exchange Act); Pitt Cites Record Number of Financial Reporting Actions, SEC. REG. \& L. RPTR. 1747 (Oct. 28, 2002) (noting that SEC brought 163 actions for financial reporting and issuer disclosure violations in fiscal 2002).

${ }^{111}$ No state has a corporate court similar to Delaware's chancery court. Only 12 other states have a consent statutes relating to directors similar to Delaware's and, to our knowledge, no other state has a consent statute relating to officers. See Kahan \& Kamar, supra note 28, at 708-715.

112 See supra note 2 . 
for defrauding the state's pension funds and other investors. ${ }^{113}$ Thus, even relative to other U.S. states, Delaware's focus on private enforcement stands out.

\section{F. The Scope of Corporate Law}

The scope of Delaware's corporate law includes the regulation of the internal affairs of the corporation and concerns the powers, rights and duties of the corporation, its shareholders, officers and directors. Matters outside the internal affairs are largely not addressed by Delaware's corporate law. Although the scope of Delaware's law in this respect is similar to the scope of corporate law in other states in the U.S., it differs from the cope of corporate law in other countries. U.K. company law, for example, contains prohibitions on carrying out a business under a misleading name, ${ }^{114}$ imposes a duty on a corporation to identify its name and characteristics in dealing with outsiders, ${ }^{115}$ regulates debentures, ${ }^{116}$ and deals with security interests. ${ }^{117}$ In the U.S., these issues are addressed by different bodies of state or federal law.

Within the confines of internal affairs, Delaware corporate law broadly covers most areas. Rules of Delaware corporate law thus govern: the creation and dissolution of a corporation; the powers of the corporation; the decision-making powers of shareholders, directors, and officers; shareholder voting; and the obligations of corporate fiduciaries. In general terms, Delaware corporate law (though not necessarily the laws of other U.S.. states) also covers much of the same territory as the federal securities laws, though it does so in a rather different manner. Federal law, for example, requires public companies to disclose a wide set of information, on a regular basis or in relation to a vote. ${ }^{118}$ Delaware law also governs the company's disclosure of information. But rather than imposing specific disclosure requirements, Delaware law requires a company to disclose all material information when shareholders are

${ }^{113}$ Oklahoma Files First Criminal Charges Against WordCom, THE InDEPENDENT, Aug. 23, 2003; see also Former Qwest Charman Anschutz to Pay \$4.4M in N.Y. State Spinning Case, SEC. REG. \& L. 857 (May 19, 2003 ) (noting settlement by corporate executive of charges brought by N.Y. Attorney General has he received profitable allocations of IPO shares by Salomon Smith Barney as an inducement or reward for investment banking business from the company). .

$$
\begin{aligned}
& { }^{114} \text { Company Act 1983, Sec. } 33 . \\
& { }^{115} \text { Id., sec. } 348 \text { - } 351 . \\
& { }^{116} \text { Id., sec. } 190 \text { - } 195 . \\
& { }^{117} \text { Id., sec. } 395 \text { - } 408 .
\end{aligned}
$$

${ }^{118}$ See Marcel Kahan, Securities Laws and the Social Costs of 'Inaccurate' Stock Prices, 1992 DuKE L. J. 977 (1992). Federal disclosure rules also apply to a company that seeks to issue shares. Delaware has no equivalent rules, presumably due to the fact that a sale of shares is outside the internal affairs of a company. 
asked to vote or to take other actions ${ }^{119}$ and grants shareholders a general right to inspect the company's books and records for a proper purpose. ${ }^{120}$ Federal law, including stock exchange rules sanctioned by the Securities and Exchange Commission, require the board of directors of public corporations, including certain committees, to contain specified percentages of independent directors. Delaware law also governs board composition. But rather than the stick of mandated requirements, Delaware law uses the carrot of granting properly constituted boards greater legal protections. ${ }^{121}$ Federal law prohibits certain forms of coercion and discrimination in tender offers. ${ }^{122}$ Delaware law subjects coercion and discrimination by the corporation to legal scrutiny for breach of fiduciary duties and permits a board wide latitude in defending itself against a coercive offers by a third party. ${ }^{123}$ Federal law criminalizes insider trading and creates a private right of action on behalf of investors. ${ }^{124}$ Delaware law create a right of action on the part of the company, enforceable through a derivative suit by shareholders. ${ }^{125}$

These differences in approach between Delaware and federal law, of course, are related to the distinctive traits of Delaware law. As noted before, much of Delaware law is judge-made and privately enforced. But the development of specific disclosure requirement, of mandated rules of board composition, of criminal violations, and even of inflexible per se rules on coercion and discrimination is hard to mesh with traditional modes of judge-made law, and specifically with the modes of privately enforced, judge-made corporate law in Delaware. Because of the distinctive traits of Delaware law, its regulation of disclosure, board composition, coercive tender offers, and insider trading, though striking in the same direction, takes a form different from federal law.

\section{Delaware's Traits as Adaptations to the Political Landscape}

\footnotetext{
${ }^{119}$ See also Erickson v. Centennial Beauregard Cellular LLC (Del. Ch. Apr. 11, 2003) (holding that disclosure statement in short-form merger did not comply with requirement to disclose all material information related to the merger to permit shareholders to make informed decision on whether to exercise their appraisal rights).

${ }^{120}$ DGCL, §220.

${ }^{121}$ Kahn v. Lynch, 638 A.2d 1110 (Del. 1994) .

${ }^{122}$ Securities Exchange Act, Section 14(d).

${ }^{123}$ Unocal Corp. v. Mesa Petroleum, 493 A.2d 946 (Del. 1985) .

${ }^{124}$ Chiarella v. U.S., 445 U.S. 222 (1980).

${ }^{125}$ See Brophy v. Cities Service Co., 31 Del. Ch. 241 (1949); Guttman v. Huang, 2003 Del. Ch. LEXIS 48, *36 ("Delaware law has long held ... that directors who misuse corporate information to profit at the expense of innocent buyers of their stock should disgorge their profit.”). As of late, Delaware seems to have become an easier venue for plaintiffs to pursue insider trading clams than the federal courts. See In re Oracle Corp. Derivative Litigation, 824 A.2d 917 (Del.Ch. 2003) (refusing to dismiss derivative insider trading claim upon recommendation of special litigation committee where similar direct claims under federal law have been dismissed for failure to meet PSLRA pleading requirements).
} 
The various traits of Delaware corporate law discussed in the last Part should all be viewed through the lens of the institutional and political landscape in which Delaware must operate. Delaware operates in a federal system in which its regulatory powers co-exist and can be constrained by the powers of the federal government and the various other states. In this system, Delaware is faced with an omnipresent, albeit not imminent, specter of a federal takeover. Such a takeover could make Delaware corporate law irrelevant, or at least greatly diminish the price companies are willing to pay to incorporate in Delaware, and thus eradicate the huge profits Delaware derives from being the domicile of choice for publicly-traded U.S. corporations. Indeed, given the historic failure of states to take significant measures to compete with Delaware for incorporations, ${ }^{126}$ the possibility of federal preemption of state corporate law due to populist pressure probably constitutes the single most important threat to Delaware's profits from the franchising business. ${ }^{127}$ Moreover, embedded in this federal system are rules on personal jurisdiction and on conflicts of laws which constrain Delaware's ability to regulate certain types of corporate conduct effectively. In this Part, we try to explain the traits of Delaware corporate law as modes of adaptation to this landscape.

\section{A. Embracing Common Law Classicism: The Creative Use of Anachronism?}

There is something determinedly old-fashioned about Delaware corporate law. The most superficial feature is the pomp and ceremony, the celebration of old distinctions like that between law and equity, the attention to tradition. ${ }^{128}$ But it goes much deeper. Delaware corporate law may be the last vestige of the old $19^{\text {th }}$ century common law style in America.

The traits of Delaware corporate law described above are striking in part because they represent a rather pure, and therefore rather unfamiliar, form of the common law system. It is worth pausing for a moment to appreciate just how much of a throwback Delaware is. The relationship between the Delaware judiciary and legislature is an example of the traditional relationship between a common law judiciary and the legislature, and illustrates one of the traditional differences between a common law and code jurisdiction. The dominance of the judiciary in making law, and the judiciary's stubborn insistence on its primacy in relation to legislation, was already described, explored and ultimately decried by Roscoe Pound in his classic 1908 article Common Law \& Legislation. ${ }^{129}$ Pound famously attacked the attitude that lay behind the $19^{\text {th }}$ century American common law judicial precept that "statutes in derogation of the common law shall be narrowly construed.” Similarly, in thinking about Delaware through

${ }^{126}$ See generally Kahan \& Kamar, supra note 28.

${ }^{127}$ See Roe, supra note 3 (noting that Delaware's chief competitive pressure comes not from other states, but from the federal government); Bebchuk \& Hamdani, supra note 78 (same).

${ }^{128}$ See, e.g., the Court of Chancery’s Home Page, http://courts.state.de.us/chancery/index.htm. See, also, The Delaware Supreme Court Golden Anniversary (Randy Holland \& Helen Winslow, eds.)(2001).

${ }^{129}$ Roscoe Pound, Common Law and Legislation, 21 HARV. L. REV. 383 (1908). 
Hart \& Sacks's conceptual framework, one is struck by the extent to which Delaware corporate law reflects a pre-New Deal understanding: no administrative agencies; private enforcement; incremental legislation from an otherwise largely passive legislature. And although never explicitly stated, the precept that "statutes in derogation of judge-made law shall be narrowly construed” offers a good guide to Delaware's corporate law jurisprudence. ${ }^{130}$

And yet we (including the Delaware judges and lawyers) are all moderns. We all know that we live in the post-New Deal Administrative State. We have all learned the lessons that the Legal Realist taught, ${ }^{131}$ and that Critical Legal Studies reemphasized: ${ }^{132}$ that law has an unavoidable political and moral aspect; that legal answers are created not discovered; that the law's affectation of technocratic expertise and neutrality is often a cover for political and normative choices. We therefore cannot assume that Delaware's embrace of the $19^{\text {th }}$ century style is simply a naive (mis)understanding of the nature of law.

What, then, could be behind this seemingly disingenuous affectation? We argue that this old common law vision, with its distinctive judicial virtues, is adaptive given Delaware's vulnerable position in the corporate law-making hierarchy. Just as the old common law style has been explained as a way that politically weak judges preserve their autonomy (or, less charitably, grab political power), so too that style can serve to aid a politically weak state in preserving its law making autonomy within a larger political landscape. By aligning itself with this history, Delaware gains legitimacy.

\section{B. Preserving the Technocratic and Apolitical Gloss}

Several of the traits described above have the effect of creating and enhancing a technocratic, apolitical gloss of Delaware law. The public perception of Delaware's corporate law as technocratic and apolitical is important for Delaware as it helps fend off federal intervention. As explained in Part I, Delaware has a legitimacy problem: why should a little state make the national rules of corporate law? By constructing its law as technocratic and apolitical, Delaware deflects attention from the democratic deficit of its corporate law, legitimizes its role as promulgator of the de facto national law, and reduces the likelihood of a populist challenge to its pre-eminence.

Several traits of Delaware law contribute to this technocratic and apolitical gloss. Consider first the breadth of judge-made corporate law. Judge-made law tends to have more of a

${ }^{130}$ See supra Section I.A..

131 See, e.g., Jerome Frank, LAW AND THE MODERN MIND 32-41 (1935).

132 See, e.g., Duncan Kennedy, Form and Substance in Private Law Adjudication, 89 HARV. L. REV. 1685, 1708-09, 1754-62 (1976). 
neutral, apolitical aura than statutory law. ${ }^{133}$ Judges are more removed from the political process and professional norms require judges to give reasoned opinions based on precedent, rather than simply doing what they think is the right thing politically. In judicial reasoning in general, and Delaware's corporate law jurisprudence in particular, partisan conflicts are not openly discussed, monetary contributions are supposed to play no role, lobbying takes the form of technical legal briefs, and political choices are swept under the carpet.

To the extent that corporate law rules are judge-made, the fact that it is Delaware judges rather than federal judges who make the rules does not much detract from the legitimacy of these rules. Judges lack obvious democratic legitimacy in any event. Rather, judicial decisions and judge-made law can be thought to derive legitimacy in the public eye ${ }^{134}$ from neutral, nonpartisan, and technical "legal” reasoning. In other words, in the public perception, federal and Delaware judges are largely interchangeable, or least much more so than federal and Delaware legislators would be. Indeed, since Delaware's judiciary is less politicized and has greater claims to expertise in corporate law than the federal one, its rulings may enjoy greater legitimacy than those of federal judges would.

The style of Delaware's judge-made law further enhances the notion that the law is technocratic and apolitical. Delaware's supreme court eschews overruling its own precedent and dissenting opinions. Instead, Delaware supreme court opinions adopt a quasi-deterministic reasoning according to which any disagreements with the chancery court or corporate actors are due to faulty legal reasoning or moral shortcomings by others. This serves to gloss over the fact that reasonable minds may differ on how an issue ought to be resolved and that the outcome of disputes depends not just on the decision maker's technical skills but on her policy preferences.

The lack of public enforcement further reduces the state's visible role in the administration of its corporate law. Rather than two state bodies (one that brings actions and another the resolves disputes), only one body - the courts - is involved. Delaware thus has no room for (over)eager, or overly lax, and possibly politically motivated law enforcers in the vein of Eliot Spitzer, ${ }^{135}$ Rudy Giuliani, ${ }^{136}$ or Harvey Pitt. ${ }^{137}$ Delaware, of course, does have courts and

${ }^{133}$ See Bebchuk \& Hamdani, supra note 78, at 604 (noting that reliance on judge-made, rather than legislative, law reduces Delaware’s legitimacy problem).

${ }^{134}$ Even though many modern legal scholars and practitioners are aware that judicial reasoning is often just a veneer that masks important and controversial decisions of a political nature, the relevant political sphere here is not legal scholars and practitioners, but the general public, which is much less aware or comfortable with judges making political choices.

${ }^{135}$ See, e.g., Michael Slackman \& Marc Santora, Spitzer, Sounding Gubernatorial, Discusses the State of the State, N. Y. TIMES, Mar. 11, 2004, B1 ("Since his election as attorney general, Mr. Spitzer has worked quietly and efficiently to position himself for a run for governor, taking on issues -- like Wall Street corruption -- that have given him a national spotlight while also working to build grassroots support across the state.”); Michael Lewis, In Defense of the Boom, N. Y. Times (MAGAZINE), October 27, 2002 at 44 ("The recent wave of outrage about Wall Street's behavior began, you may recall, when New York State Attorney General Eliot Spitzer deployed an obscure state law to shoehorn out of Merrill Lynch every e-mail message Merrill employees had ever sent relating to the 
judges. But judges are brought to the fore through the decentralized activities of private actors rather than on their own motion, lack the power and staff to conduct investigations, and are supposed to exercise restraint in commenting on disputes. Delaware's judiciary, in particular, is highly respected for its technocratic expertise and a model of non-partisanship. The focus on enforcement of Delaware corporate law through actions initiated by private parties and resolved by Delaware courts thus supports the apolitical and technocratic image of the law.

The extra-cameral activities by members of the Delaware judiciary also mesh well with Delaware’s political interests. These activities help market Delaware law to the legal community; let judges obtain information about the views of practitioners and academics; and enable the judiciary to amplify their admonitions to directors to comport with the judiciary's vision of proper corporate governance and thus beef up Delaware's enforcement regime. In all these respects, they make Delaware more attractive as an incorporation haven. But, from our perspective, they also serve an additional function: they create an outlet for dissatisfaction with legal rulings and permit individual members of the judiciary to refine, confine, and maybe even signal a retreat from the court's holdings. The need for this outlet is created by the fact that, as judges, members of Delaware's judiciary cannot be directly lobbied; that practicing lawyers may be reluctant to criticize judicial rulings openly; and that the judiciary lacks control over its docket and thus may value the opportunity to clarify their holdings before the next case involving that issue arises.

Even in the matters into which the legislature does intrude, Delaware law has - in this instance deservedly - a technocratic and apolitical appearance. Proposed laws are adopted without amendment or debate, by overwhelming majorities. Any lobbying that takes place occurs within the corporate law section of the Delaware bar. Thus, even within the legislative process, the dirty portions of politics either do not exist or at least are not visible: Campaign contributions, partisanship, and even the special interests of local constituents have no apparent

Internet boom. It was easy to see why Spitzer chose Merrill Lynch as his target. He has political ambitions (he wants to be governor of New York, at least), and unlike Goldman, Sachs or Morgan Stanley or one of the other big investment banks more central to the Internet bubble, Merrill actually serviced lots of small customers. It's a firm that voters can relate to.”).

${ }^{136}$ See, e.g., Catharine S. Manegold, A Road of Many Turns, an End Triumphant: Rudolph William Giuliani, N. Y. TIMES, Nov. 3, 1993 at B3 ("Campaigning for mayor, Mr. Giuliani always said his quest was a natural progression in a career that took him from the Federal prosecutor's office in Manhattan to the No. 3 official in the Reagan Justice Department and finally United States Attorney for the Southern District of New York. . . He became famous for his prosecution of organized crime figures and insider trading. The names Milken, Boesky and Drexel-Burnham Lambert were linked with his after he led a series of assaults against Wall Street's excesses.”).

${ }^{137}$ Harvey Pitt, who had been hailed on his appointment as chair of the SEC, was ultimately forced to resign in the wake of accusations of laxity in response to the corporate and accounting scandals. Stephen Labaton, Praise to Scorn: Mercurial Ride Of S.E.C. Chief, N. Y. Times, Nov. 10, 2002, at 1 (article includes discussion of Pitt's "decision to press the enforcement staff to file a securities fraud lawsuit against WorldCom only a day after it disclosed its problems.”). 
effect on the law and lobbying is channeled through a professional, consensus-oriented body that meets outside the public's eye and self-consciously avoids taking on controversial issues.

This is not to say that Delaware politics are generally more pure than elsewhere or that a large in-state interest, be it a large local corporations such as DuPont or MBNA or chicken farmers from the southern part of the state, do not have significant influence in Delaware politics. It is not. But precisely because local Delaware politics is impure, it is imperative for Delaware to assure, as much as possible, that the corporate lawmaking process is not, or is perceived not to be, the product of ordinary politicking. Few things would do more to undermine Delaware's legitimacy than, say, a front-page article in a major newspaper discussing how a large corporation got some controversial legislation passed by channeling substantial contributions to local politicians. ${ }^{138}$

\section{The Minimization of Interjurisdictional Conflict}

Another way that Delaware adapts to its position in the federal system is to take account of the rules on personal jurisdiction and conflicts of law to avoid interjurisdictional conflicts. Under the due process clause of the U.S. constitution, state courts can assert jurisdiction only over defendants who have the requisite minimum contacts with the forum state. Under prevailing rules on conflict of laws, which are part of the law of each state, the law of the state of incorporation governs the internal affairs of the corporation, but other factors determine the law applicable to most other disputes. These jurisdictional and conflict rules help explain the scope of Delaware's corporate law.

Consider, for a moment, how narrow Delaware's corporate law is. It is largely confined to the regulation of the internal affairs of the corporation. This scope is due neither to some inherent understanding of what corporate law is about - U.K. company law encompasses a number of other matters - nor to Delaware not being able to offer a superior substantive product on other matters - because of its quality courts and its responsiveness, it well could. Rather, it is due to conflict of law rules which would generally not point to the law of the state of incorporation as governing matters outside the internal affairs of the corporation.

Of course, Delaware could revise its own conflict rules to point to Delaware law as governing matters outside the company's internal affairs. But Delaware could not force other states to do the same. Thus, depending on whether a dispute is litigated in Delaware or a different forum, the forum's conflict rules would point to different bodies of law, with possibly different substantive content. As a result, parties would not know which substantive rules apply before a lawsuit is brought. Even if Delaware law were substantively superior to the law of other states, parties may well prefer to know with certainty that they are governed by the (inferior) law

\footnotetext{
${ }^{138}$ Cf. Andrew Ross Sorkin, Michigan Senate Approves Change in Takeover Laws, N.Y. TIMES, Sep. 19, 2003, at C4 (noting that intense lobbying effort by Taubman family lead to passage of legislation that would enable the Taubmans to block hostile bid for its shopping mall empire); Spitzer v. Grasso, WALL ST. J., May 25, 2004 at A16 (suggesting that Spitzer failed to sue fellow Democrat McCall for political reasons).
} 
of, say, Maryland, to uncertainty over whether (inferior) Maryland law or (superior) Delaware law applies. ${ }^{139}$

Moreover, Delaware has a lot to lose from challenging the prevailing rules on conflict of laws. If Delaware is perceived as being overly aggressive in expanding its own law to areas that are not traditionally subject to laws of the state of incorporation, other states may respond by changing their conflict rules to limit the scope of the internal affairs rule. The continued applicability of the internal affairs rule is, of course, the life-blood of Delaware. Thus, Delaware has no interest to pursue a major change of the status quo of conflict rules.

Furthermore, Delaware would only have a limited ability to enforce many rules that would fall outside the internal affairs doctrine. To enforce its law effectively, Delaware courts needs personal jurisdiction over the relevant defendants. Such jurisdiction would be lacking, say, over a creditor who claims a security interest in the company's property - an issue regulated by U.K. company law, but not by Delaware corporation law. ${ }^{140}$

Limitations imposed by personal jurisdiction may also affect how Delaware regulates the internal affairs. Thus, Delaware law imposes no duties on shareholders (unless they are controlling shareholders) ${ }^{141}$ or on a bidder to structure tender offers in a certain manner. ${ }^{142}$ Such rules may well complement the governance structure established by Delaware's corporate law. But because being a shareholder of or a bidder for shares of a Delaware corporation would be

\footnotetext{
${ }^{139}$ Parties can, of course, include forum and law selection clauses in contracts, but many of the areas where Delaware's superiority would be most significant, such as products liability, involve tort rather than contract claims.

${ }^{140}$ See supra Section II.F.

${ }^{141}$ Though having control of a Delaware corporation is not a sufficient basis for personal jurisdiction, individual controlling shareholders will often be directors and corporate controlling shareholders will usually be under a duty to indemnify their representatives on the board of the controlled company, and thus be subject to the de jure or de facto jurisdiction of the Delaware courts. Grace Brothers, Ltd. v. Uniholding Corp., 2000 Del. Ch. Lexis 101 (rejecting argument that controlling shareholder is indispensable party and exercising jurisdiction over individual directors, who held large stake in controlling shareholder, noting that directors can seek indemnification or contribution from controlling shareholder in a separate action). Moreover, Delaware employs the far-reaching conspiracy theory to obtain personal jurisdiction over controlling shareholders. See, e.g., Parfi Holding AB v. Mirror Image Internet, 794 A.2d 1211 (Del. Ch. 2001), rev'd on other grounds 817 A.2d 149 (Del. 2002) (basing jurisdiction on conspiracy theory which requires that controlling shareholder participated in conspiracy and had reason to know that substantial act or effect in furtherance of conspiracy occurred in forum state); Gibralt Capital Corp. v. Smith, 2001 Del. Ch. Lexis 60 (same).

${ }^{142}$ Such duties do exist under U.S. federal law or U.K. company law. Securities Exchange Act, Sec. 13(d), 14(d); Company Act 1985, sec. 198 - 210A. (tender offer rules). Curiously, Delaware’s corporation law has a "reorganization" section which permits companies to insert a clause in their charter that would permit a requisite majority of creditors (majority in number, $3 / 4$ in value) to approve a compromise or arrangement which, if approved by the court, be binding on all creditors. See §102(b)(2). It is unlikely that the Delaware court have the jurisdiction over creditors to enforce this section and it does not appear it that it is ever used. See Edward P. Welch \& Andrew J. Turezyn, FolK ON THE DELAWARE GENERAL CORPORATE LAW, at GLC-I-21 (citing no relevant cases in commentary on section).
} 
unlikely to satisfy the constitutional requirement of minimum contacts, Delaware courts would lack the ability to enforce such duties effectively.

\section{Implications and Explorations}

\section{A. Responding to Crises}

Delaware corporate law's adaptive adherence to the old common law model carries inherent limitations that can bind uncomfortably when crises arise. In this regard, contrast the different responses to the post-Enron sense that "something must be done." Congress held hearings and ultimately enacted the Sarbanes-Oxley Act. The Securities and Exchange Commission, on its own accord and in response to Congressional dictate, adopted new regulations and leaned on the stock exchanges to reform their corporate governance standards for listed companies. Several states have passed news laws or instituted criminal proceedings against executives involved in the scandals.

Compare this to Delaware. Its legislature did not act - it did not hold any hearings and did not pass any legislation - because it eschews controversy. No administrative agency promulgated new rules because Delaware has no parallel to the Securities and Exchange Commission. No public prosecutor went on the warpath against corporate wrong-doers because Delaware corporate law is enforced by private actions. Given Delaware's traditional mode of addressing controversy, it had to wait until a legal dispute was brought in its courts. But even in this regard, Delaware had no opportunity to address the recent scandals directly. In short, Delaware has been out of the limelight.

This does not mean, however, than Delaware has been out of the loop. It is much too early to tell what effect the recent scandals will have on Delaware law. We will not know until, several years hence, we look back and trace out the various ways in which the lessons of Enron, etc. - whatever they turn out to be - are, incrementally and slowly, incorporated and expressed in Delaware judicial review of board conduct. ${ }^{143}$

Some may lament that Delaware is being slow to respond. But that is to miss a very important point: Delaware's slowness is part and parcel of its adherence to a particular, traditional, reactive model of judge-centered lawmaking. That adherence, as we have argued, is

\footnotetext{
${ }^{143}$ We can already see some subtle signs that Delaware law will be changing. For example, in In re Oracle Corp. Derivative Litigation, 824 A.2d 917 (Del.Ch. 2003), Vice-Chancellor Strine employed an narrow concept of independence -- one that takes account of the fact that interests that are not directly financial, such as collegiality among members of the same faculty or charitable donations to a faculty member's university can impinge on one's independence - in refusing to dismiss a complaint upon the recommendation of a special litigation committee. And in In re Walt Disney Co. Derivative Litigation, 825 A.2d 275 (Del.Ch. 2003), Chancellor Chandler refused to dismiss a complaint that a senior officer received an overly generous severance package on the grounds that the alleged lack of board involvement in structuring the severance package may amount to lack of good faith and board members may thus not be protected by Section 102(b)(7). In addition, the Delaware judiciary has been out on the hustings trying to send a message. See, e.g., Chandler \& Strine, supra note 100.
} 
an adaptation to the federalist landscape in which it operates. To deviate in response to some felt necessity would probably be wrong headed. If Delaware were to try to out-reform Congress and the Securities and Exchange Commission, it would be bound to lose because of its inherent disadvantage in legitimating the provision of national law.

Contrast, in this respect, Delaware's passivity with the activity of Eliot Spitzer, who has managed to sideline the SEC on several fronts. Spitzer is the Attorney General is one of the largest states, the geographic home of the major stock exchanges and investment banks and of numerous investors. As such, Spitzer's democratic legitimacy greatly exceeds Delaware's. But much more importantly, Spitzer, one suspects, is less concerned about preserving New York's long-term regulatory powers than about dealing with the current crisis and earning the financial (for the state) and political (for himself) rewards from being visibly on the ball while the Securities and Exchange Commission was asleep. Thus, even if, as is likely, the SEC ultimately reasserts its preeminence in regulating the securities industry and fends off future interference by state regulators, ${ }^{144}$ Spitzer will come out a winner. By contrast, any move by Delaware that earns it short-term plaudits but undermines its long-term status as corporate domicile would make it a loser.

\section{B. The Symbiotic Relationship between Federal Law and Delaware Law}

Delaware's adherence to a traditional common law model and the rules on jurisdiction and conflict of laws also constrain its ability to regulate. Where rules are required (or thought to be required) that Delaware is unwilling (because it would in tension with the common law model) or unable (because of jurisdictional and conflict rules) to supply, any such regulations would be left to a hodgepodge of state rules or, if a national solution is desirable, would have to be imposed by the federal government.

One example of rules that would be difficult for Delaware to supply are the mandatory disclosure rules imposed by the federal securities laws. Consider, first, the logistical requirements. The SEC's Division of Corporate Finance alone has about 400 employees, ${ }^{145}$ far more than the whole of the Chancery and Supreme Courts of Delaware. To be able to devise a similarly detailed regulatory regime, Delaware would thus have to change its lawmaking infrastructure radically. It could no longer rely on a small body of judicial officers, but would

\footnotetext{
${ }^{144}$ For efforts in that vein, see Judith Burns, SEC Warns of Uncoordinated Inquiries, WALL. ST. J., Sep. 10, 2003, at C14 (noting complaint by SEC chairman that states official act for political gain and compromise federal investigations in the process); Morgan Stanley Case Illustrates States’ Strategy, WALL. ST. J., Jul. 15, 2003 at C1 (noting passage of bill by House Financial Services subcommittee that would weaken states' ability to regulate securities industry).

${ }^{145}$ In fiscal year 2003, the division had 438 positions. See www.sec.gov/news/testomony/ts072303pd.htm.
} 
instead have to establish a major regulatory agency with a number of employees and a budget closer to the SEC’s. ${ }^{146}$

Doing so, however, would generate two problems. First, it would bring to the fore issues of democratic legitimacy that Delaware would rather have remain obscure. In particular, the adoption and revision of regulations would entail more explicit law-making - and thus make controversial political and normative choices more manifest - than the present mode. Second, adopting a comprehensive regulatory regime would be hampered by conflicts rules and jurisdictional limitations. Unlike conflict rules on the internal affairs of a corporation, conflict rules on disclosure regulations with respect to the issuance and trading of securities do not point to state of incorporation as applicable. ${ }^{147}$ In addition, Delaware lacks personal jurisdiction over various parties subject to the federal regime, such as broker/dealers, $5 \%$ shareholders, shareholders engaged in secondary offerings of securities, shareholders who solicit proxies, accounting firms, and employees engaged in insider trading. Delaware courts would thus lack the ability to enforce the regulatory regime on these parties, which would be likely to diminish greatly the effectiveness of any regulatory structure.

More generally, there are several types of rules that Delaware is unlikely to supply and where federal regulation may (if the requisite rules are indeed efficient) be desirable. The first type concerns issues where prevailing state conflict rules do not point to the state of incorporation. These include, for example, fraud in connection with the sale of securities under Section 11 of the Securities Act and Section 10(b) of the Securities Exchange Act or the manipulation of security prices. ${ }^{148}$

The second type concerns issues where individual states cannot constitutionally exercise personal jurisdiction over the relevant defendants. ${ }^{149}$ Regulations under the Williams Act of bidders and 5\% shareholders, regulations of broker/dealers, disclosure requirements for large shareholders under Section 16 of the Exchange Act, the prohibition against "insider" trading under the misappropriation theory are examples of rules that Delaware could not effectively enforce because its courts would lack the requisite personal jurisdiction over most defendants.

The third type concerns issues where public enforcement is preferable to private enforcement. This includes misconduct that is so severe than criminal penalties are warranted and prophylactic rules where enforcement though an administrative agency is superior to private

\footnotetext{
146 The SEC's budget is \$716 million. See www.whitehouse.gov/omb/budget/fy2004/ Delaware’s entire budget outlays for the Division of Corporations, the court of chancery and the supreme court is about $\$ 10$ million.

147 See Romano, supra note 36, at 2402 - 2412 (proposing change in choice-of-law rules to operationalize proposed state competition over securities regulation).

${ }^{148}$ Securities Exchange Act, $\$ 9$ and regulations thereunder..

${ }^{149}$ Note here special broad rules on venue and jurisdiction in securities lawsuits. Securities Exchange Act, $\S 27$.
} 
enforcement. An example of the latter may be rules against selective disclosure of information like Regulation FD, violations of which may be publicly enforced but cannot form the basis of a private lawsuit. ${ }^{150}$

The fourth type concerns issues where a detailed rule-based ex ante regulatory regime is desirable. An example may be the adoption of accounting rules guiding the manner in which a company must disclose financial information, other specific disclosure obligations, or specific rules exempting certain companies, securities, or transactions from certain obligations.

The fifth type concerns issues which are so openly political that they cannot be effectively adopted through a common-law judge-made system. An example would be the institution of a codetermination regime, as it prevails in Germany, where employees have substantial representation of the board of directors. A U.S. example might be the adoption of the Foreign Corrupt Practices Act which prohibited the payment of bribes, without regard to their effect on the firm. ${ }^{151}$

Finally, our analysis points to a sixth type of issue that Delaware, although it may be able to regulate as effectively as a federal lawmaker, would gladly yield to the feds. These are issues that are both inherently difficult to regulate effectively and are particularly likely to trigger a populist response. The prime example of such a "hot potato" issue is executive compensation, a topic regulated (ineffectively) by both federal and state law that regularly invites populist anger over the stellar income of (not always stellar performing) executives.

Federal law in any of these areas does not necessarily undermine Delaware's position as national provider of corporate law. To the contrary. If Delaware is not able to regulate certain conduct effectively, it is probably in its interest to have this conduct regulated on the federal level (or by other states) to fill the lacunae in its own law. Without such federal regulation, continued and unsanctioned wrongdoing could result in a populist backlash against Delaware as the provider of an ineffective regulatory regime and lead to a wholesale replacement of Delaware law. Federal regulation can thus strengthen Delaware's long-term position in two ways. First, by making the system as a whole less scandal-prone, thus reducing the likelihood of a populist attack. Second, to the extent that scandals nevertheless ensue, a federal regulatory system provides an alternative target - a lightening rod from Delaware's perspective - for a populist attack. Indeed, the federal regime - being more openly political, partisan, and publicly enforced - may well make a more inviting target than Delaware. ${ }^{152}$

\footnotetext{
${ }^{150}$ Reg. FD, Rule 102.

${ }^{151}$ Cite.

152 In the recent scandals, for example, greater blame was given to the SEC than to Delaware. See, e.g., Stephen Labaton, Praise to Scorn: Mercurial Ride Of S.E.C. Chief, N. Y. Times, Nov. 10, 2002, at 1.
} 
Thus, while Delaware lives under the constant threat of federal preemption, there is as well a significant symbiotic element to the relationship between federal and Delaware law.

Delaware benefits from federal regulation, as long as it is in the right areas and of the right sort.

\section{Conclusion}

The recent corporate scandals, and the various reactions of the different regulatory actors, provide an opportunity to tease out some important features of our corporate law federalism. In this Article, we have argued that Delaware corporate law, and Delaware's reaction to corporate crises, must be analyzed from within the institutional and political landscape in which Delaware's regulatory powers coexist with, and can be constrained by, the powers of the federal government and the various other states. From this perspective, the seemingly archaic $19^{\text {th }}$ century common law style of Delaware corporate law making can be understood as a creative use of anachronism, as an invocation of apolitical technocratic expertise as a way of making up for an arguable lack of democratic legitimacy. At the same time, the scope of Delaware's law is crafted in a way that minimizes conflicts with other jurisdictions. Because of the constraints placed on Delaware by the federalist structure, the relation between federal law and Delaware law can be best understand as symbiotic as well as antagonistic. Although Delaware is threatened by federal preemption, it is also served by federal regulations that regulate areas which Delaware cannot regulate effectively and thus help ward-off crises or provide a lightening rod for a populist backlash which could produce more severe harm. 
Figure 1. Allocation of Corporate Law-Making Authority.

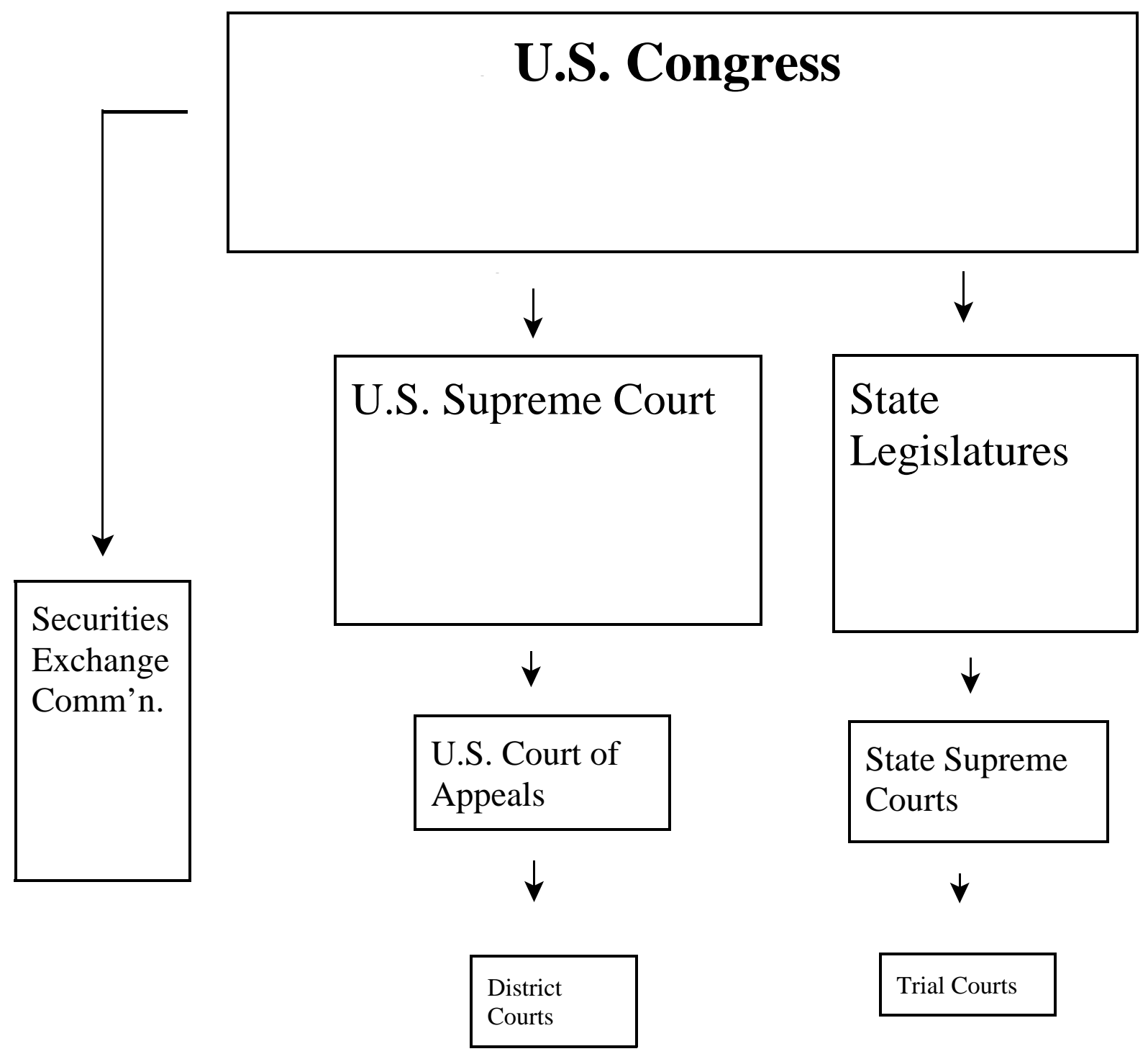

Constituencies/customers:

Investors

Employees $\quad$ Managers

Corporate Lawyers

Corporations 
Figure 2: The Lawmaking Role

The Lawmaking Machinery

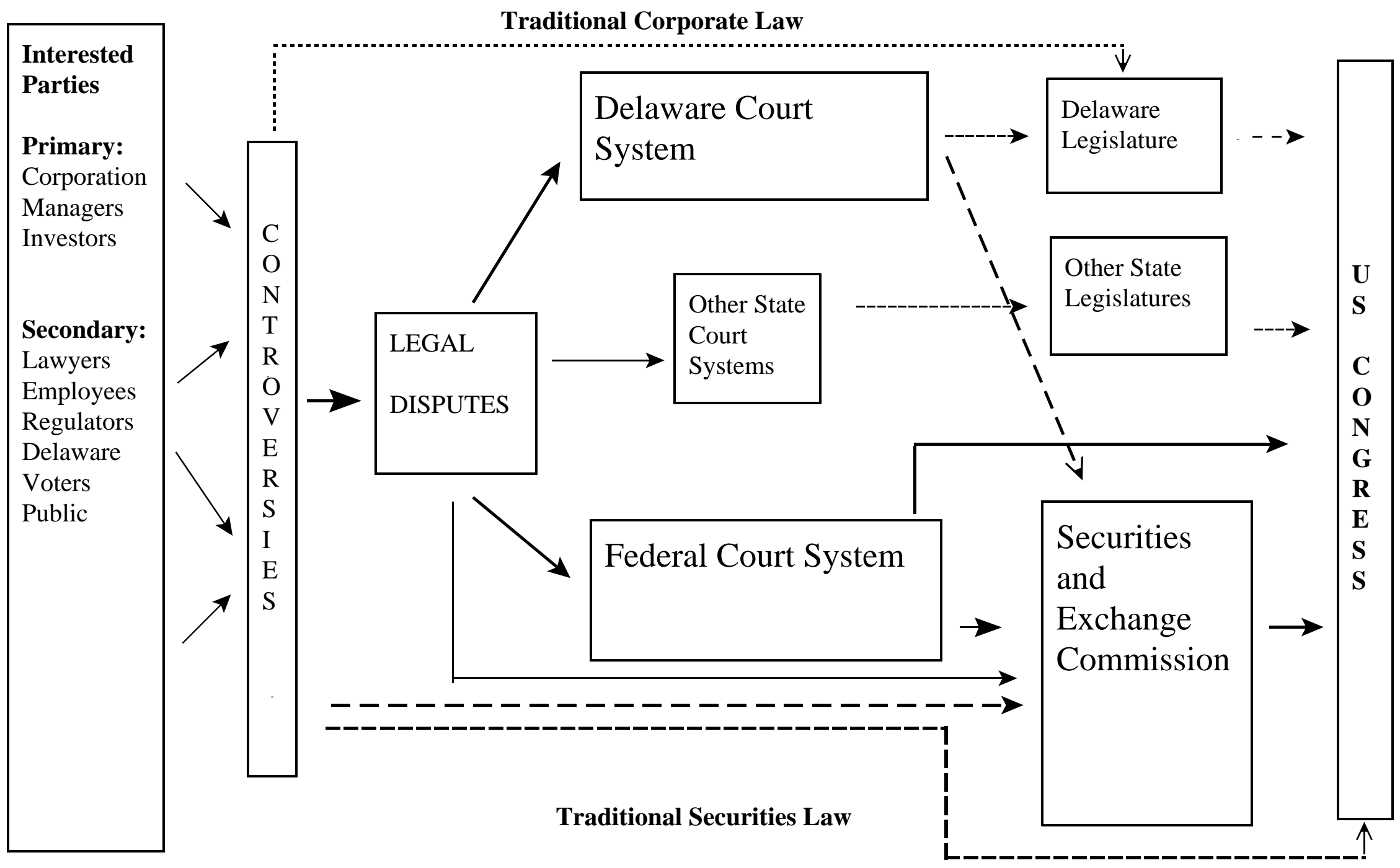

